\title{
ESTIMAÇÃO DE EQUAÇÃO DE OFERTA DE EXPORTAÇÃO DE FRANGO PARA O BRASIL (1991/2000)
}

\author{
SANDRO EMÍLIO BORTOLIN \\ Economista
}

Orientador: Prof(a). Dr(a). MIRIAN RUMENOS P. BACCHI

Dissertação apresentada à Escola Superior de Agricultura "Luiz de Queiroz", Universidade de São Paulo, para obtenção do título de Mestre em Ciências, Área de Concentração : Economia Aplicada

P I R A C I C A B A

Estado de São Paulo - Brasil

Fevereiro - 2002 


\section{Dados Internacionais de Catalogação na Publicaçāo (CIP)}

DIVISĀO DE BIBLIOTECA E DOCUMENTAÇĀO - ESALQ/USP

\section{Bortolin, Sandro Emílio}

Estimaçāo de equação de oferta de exportação de frango para o Brasil

(1991/2000) / Sandro Emílio Bortolin. - - Piracicaba, 2002.

\section{$96 \mathrm{p}$.}

Dissertaçāo (mestrado) - - Escola Superior de Agricultura Luiz de Queiroz, 2002. Bibliografia.

1. Exportação 2. Frangos 3. Indústria agrícola 4. Mercado internacional I. Título

CDD 338.1765 


\section{AGRADECIMENTOS}

Diversas pessoas colaboraram para a conclusão deste trabalho.

Por seu apoio e incentivo inicial, agradeço ao Professor José Eurico Possebon Cyrino, meu amigo pessoal e pessoa de elevada estima.

Meu especial agradecimento aos colegas do Banco do Brasil S/A, agência Jaboticabal, Evandro, Maria Donizete, Mirtes, Sergio Savik e Carlos Henrique pelo apoio e constante estímulo à conclusão deste trabalho.

Agradeço aos funcionários do Departamento de Economia, Administração e Sociologia, especialmente às funcionárias Maria A. Maielli Travalini e Ligiana Clemente do Carmo, pela infinita paciência e inúmeras solicitações atendidas.

Agradeço ao Professor Carlos José Caetano Bacha por sua confiança no meu trabalho e ao Professor Ricardo Shirota pelo incentivo e importantes sugestões.

Especial agradecimento à Professora Mirian Rumenos Piedade Bacchi por sua confiança, persistência e valiosa orientação.

À minha família, em especial à minha esposa, Teresa, e a meu filho, Pedro, que com muito carinho e paciência contribuíram e deram sentido à realização deste trabalho. 


\section{SUMÁRIO}

Página

LISTA DE FIGURAS................................................................................ vi

LISTA DE TABELAS......................................................................................... vii

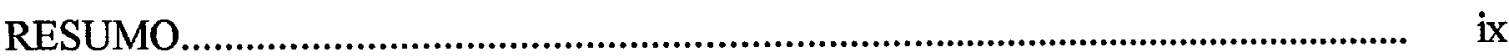



1 INTRODUÇÃO........................................................................................ 1

1.1 Justificativa............................................................................................. 1

1.2 Importância do estudo.........................................................................................

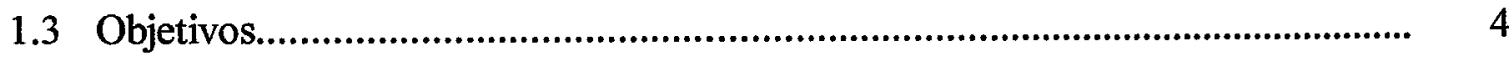

2 REVISÃO DE LITERATURA............................................................. 5

2.1 O mercado de frango: surgimento e consolidação da indústria avícola .............. 5

2.2 Inserção do Brasil no mercado internacional de aves.......................................... 17

2.3 Modelagem básica........................................................................................ 25

2.4 Modelos teóricos utilizados na estimação de equações de exportação............... 27

3 METODOLOGIA.................................................................................... 58

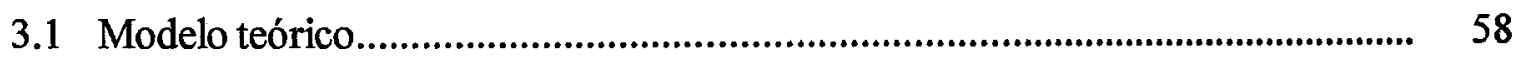

3.2 Modelo empírico........................................................................................... 60

3.3 Procedimentos econométricos............................................................................ 62

3.4 Dados utilizados........................................................................................... 77

$4 \quad$ RESULTADOS E DISCUSSÃO.................................................................... 79

4.1 Resultados dos testes de raiz unitária.................................................................... 79

4.2 Resultados dos testes de co-integração................................................................. 83

4.3 Resultados da estimativa do Modelo de Correção de Erro (MCE)...................... 84 


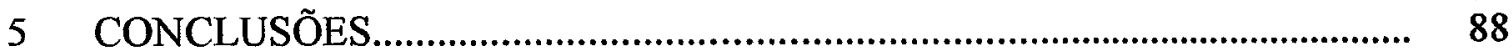

REFERÊNCIAS BIBLIOGRÁFICAS .................................................. 92 


\section{LISTA DE FIGURAS}

Página

1 Diagrama ilustrativo do processo de produção de matrizes para criação de frangos de corte no Brasil .......................................................................... 8

2 Exportação brasileira de frangos - inteiro e cortes - 1975/2000 (toneladas)....... 20

3 Função de oferta de exportação..................................................................... 56

4 Procedimento seqüencial para testar a presença de raiz unitária...................... 67 


\section{LISTA DE TABELAS}

Página

1 Evolução no consumo anual per capita de carne de frango no Brasil de 1970 a 2000

2 Principais linhagens de aves comercializadas, seus representantes e as respectivas participações nos mercados brasileiro e mundial - 1992..................... 9

3 Evolução da conversão alimentar obtida para o frango de corte no Brasil........... 11

4 Maiores empresas produtoras de aves no Brasil - 2000 (milhões de aves) ......... 15

5 Evolução da produção e exportação de carne de frango (inteiro e em partes) e suas respectivas participações no montante exportado pela indústria brasileira de frangos (1975/2000).............................................................................. 19

6 Produção mundial de carne de frango/maiores produtores (mil toneladas).......... 22

7 Exportações brasileiras de carne de frango por destinos selecionados 1999/2000 (toneladas)............................................................................................ 23

8 Coeficientes das equações na forma reduzida do modelo de equilibrio................ 31

9 Coeficientes das equações na forma reduzida do modelo de desequilibrio.......... 34

10 Sumário dos testes de Dickey-Fuller..................................................................... 66

11 Resultados de AIC e SC das séries consideradas na função de oferta de exportação de frango...................................................................................... 81

12 Resultados dos testes de identificação de raiz unitária e de elementos determinísticos das séries, em nível, utilizados na estimação da função de oferta de exportação de frango

13 Resultados dos testes de identificação de raiz unitária e de elementos determinísticos das séries, nas primeiras diferenças, utilizadas na estimação da 
função de oferta de frango............................................................................... 83

14 Resultados dos testes de co-integração obtidos através do procedimento de máxima verossimilhança de Johansen.................................................................... 84

15 Resultados da estimativa do Modelo de Correção de Erro utilizado para explicar a oferta de exportação brasileira de frango................................................. 85 


\title{
ESTIMAÇÃO DE EQUAÇÃO DE OFERTA DE EXPORTAÇÃO DE FRANGO PARA O BRASIL (1991/2000)
}

\author{
Autor: SANDRO EMÍLIO BORTOLIN \\ Orientadora: Prof(a). Dr(a).: MIRIAN RUMENOS PIEDADE BACCHI
}

\section{RESUMO}

O presente estudo foi elaborado com o objetivo de analisar a oferta de exportação brasileira de frango através da estimação de um modelo econométrico. As exportações de carne de frango vêm aumentando sua importância relativa na pauta das exportações brasileiras de produtos agropecuários. Isso tem sido atribuído, principalmente, às condições altamente competitivas resultantes de um intenso desenvolvimento de produtos que atendem às preferências dos consumidores, além de inovações tecnológicas implementadas pelo setor. Para analisar as exportações brasileiras de frango, ajustou-se um modelo teórico que especifica a oferta de exportação como resultado da diferença entre a oferta e demanda internas. Como variáveis explicativas para o referido modelo, utilizaram-se a série de preço interno, a de preço externo, a de renda interna e a de taxa de câmbio real. As respectivas elasticidades encontradas apresentaram sinais coerentes com a teoria econômica e com o modelo delineado para a análise. O modelo econométrico ajustado por Mínimos Quadrados Ordinários (MQO) incluía um termo de correção de erro, uma vez que as séries são integradas e co-integradas. Dentre as variáveis consideradas no modelo, a que apresentou o maior coeficiente em valores absolutos foi a renda interna - uma variação de $1 \%$ na renda interna causa uma variação 
de aproximadamente $1,35 \%$, em sentido contrário, nas exportações. Torna-se evidente, portanto, que o crescimento da economia doméstica impacta negativamente as exportações, sendo verdadeiro o inverso. Esse resultado indica que não é necessária a adoção de medidas intervencionistas para garantir o abastecimento doméstico, visto que o próprio mercado providencia os ajustes necessários para a manutenção do equilíbrio entre oferta e demanda. A elasticidade encontrada para o preço doméstico de frango indica que mudanças nessa variável teriam impacto relativamente pequeno sobre as exportações - uma variação de $1 \%$ nessa variável produziria uma variação percentual de 0,33 na quantidade exportada. $O$ efeito de mudanças na taxa de câmbio real mostrou-se relativamente importante para estimular as exportações de carne de frango - um aumento de $1 \%$ na taxa de câmbio provoca uma elevação de $0,46 \%$ nas exportações do produto, após o período de dois meses. O coeficiente da variável preço externo, embora seja positivo como esperado, apresentou-se não-significativo estatisticamente, indicando que ele foi estimado com baixa precisão. A magnitude do coeficiente estimado indica que uma alteração de $1 \%$ no preço externo ocasionaria um aumento de aproximadamente $0,44 \%$ na quantidade exportada, após três meses. Em termos gerais, dentre as variáveis relacionadas no modelo, a renda interna e a taxa de câmbio efetiva apresentaram as maiores elasticidades. $O$ preço externo e o preço interno, embora afetem as exportações brasileiras de frangos, fazem-no de forma menos expressiva para uma mesma variação percentual. Torna-se evidente, pelos resultados obtidos, que as exportações brasileiras de frango dependem, em grande parte, de um ambiente macroeconômico adequado, uma vez que as duas variáveis mais relevantes na explicação das exportações são a renda interna e a taxa de câmbio. Contudo, pode-se concluir que investimentos em tecnologia, extremamente importantes para a geração de excedentes exportáveis, são imprescindíveis para o bom desempenho das exportações. 


\title{
ESTIMATE OF BRAZILIAN POULTRY EXPORT SUPPLY EQUATION
}

(1991/2000)

\author{
Author: SANDRO EMÍLIO BORTOLIN \\ Adviser: Prof. Dr. MIRIAN RUMENOS PIEDADE BACCHI
}

\section{SUMMARY}

The objective of this study was to analyze Brazilian poultry export supply through an econometric model. The importance of exports of poultry meat has increased considerably in the total Brazilian agricultural foreign sales. This is especially due to highly competitive conditions resulting from both an intensive development of products that meet consumers' preferences and technological innovations implemented in the sector. For the analysis of Brazilian exports of poultry, a theoretical model was developed which specifies the exports supply as a result of the difference between the internal supply and demand. The explanatory variables used for the model were the internal price, external price, internal income and real exchange rate series. The elasticities found presented signs that were coherent both with the economic theory and with the model developed for the analysis. The econometric model adjusted by Ordinary Least Squares (OLS) included an error correction term once the series are integrated and co-integrated. Among the variables considered in the model, the one which presented the highest coefficient in absolute value was the internal income - a variation of $1 \%$ in the internal income provokes a variation of about $1.35 \%$, in the contrary direction, in exports. Therefore, the fact that the growth in domestic economy has a negative impact in exports and that the 
inverse is also true becomes evident. This result shows that the adoption of intervention measures in order to guarantee the domestic supply is not necessary, since the market itself makes the necessary adjustments to maintain the balance between supply and demand. The obtained domestic price elasticity for poultry indicates that changes in this variable would have a relatively low impact on exports - a variation of $1 \%$ would produce a percentile variation of $0.33 \%$ in the exported amount. The effect of changes in the real exchange rate was relatively important to stimulate poultry meat exports - an increase of $1 \%$ in the exchange rate provokes an elevation of $0.46 \%$ in exports after a period of two months. The external price variable coefficient, in spite of being positive, as expected, was statistically insignificant, showing that it was estimated with low precision. The magnitude of the estimated coefficient shows that an alteration of $1 \%$ in the external price would result in an increase of approximately $0.44 \%$ in the exported amount after a period of three months. In general, among the variables used in the model, the internal income and the effective exchange rate had the highest elasticities. Although the external and internal prices affect Brazilian exports of poultry, they do it less expressively for the same percentile variation. The results show that Brazilian poultry exports depend greatly on an adequate macroeconomic environment once the most relevant variables in the explanation of exports are the internal income and the exchange rate. However, we have concluded that more investments on technology, which is highly important for the generation of exportable surplus, are cardinal for the good development of exports. 


\section{INTRODUÇÃo}

\subsection{Justificativa}

As relações comerciais internacionais estão intimamente ligadas à busca do equilíbrio nas economias dos países em desenvolvimento. No Brasil, embora o crescimento das importações, como conseqüência da liberalização comercial, tenha recebido especial atenção nas discussões que tratam do comércio internacional, sabe-se que as exportações representam importante papel no processo de ajustamento das contas externas.

As exportações proporcionam recursos para manter o fluxo de bens de capital necessário ao desenvolvimento do país e, desta forma, elas adquirem especial importância por serem não apenas um elemento de ajuste das contas externas, mas também de manutenção dos níveis de crescimento da economia e emprego. A dinamização das exportações é necessária, segundo Cavalcanti \& Ribeiro (1998), por dois aspectos básicos. Em primeiro lugar, o ritmo de crescimento das exportações deve ser tal que compense, pelo menos parcialmente, o crescimento das importações, evitando a existência de déficits comerciais elevados. Em segundo lugar, as exportações devem garantir a sustentabilidade da trajetória do endividamento externo, decorrente da absorção de poupança externa necessária para financiar os investimentos nacionais de paises em desenvolvimento. 
Atualmente, um dos principais temas de debates de política econômica brasileira refere-se ao desempenho das contas externas do país, especialmente da balança comercial, que passou de superavitária até 1994 para deficitária, depois desta data. A abertura comercial iniciada no final da década de 80 e deflagrada no início dos anos 90 juntamente com a política econômica adotada pelo governo brasileiro após a implementação do Plano Real são apontadas como as principais causas dos constantes déficits apresentados pela balança comercial brasileira nos últimos anos. ${ }^{4} \mathrm{~A}$ adoção, em janeiro de 1999, de um regime de câmbio flutuante concomitante a uma desvalorização cambial gerou uma expectativa de melhora da balança comercial devido a um aumento esperado das exportações e à queda nas importações. Entretanto, tal recuperação não ocorreu, pois as commodities agrícolas, principal categoria de produtos exportáveis brasileiros, têm registrado queda de preços (Castro \& Rossi Junior, 2000). Este fato acentua o interesse pelo comportamento das exportações e, em especial, dos produtos agropecuários, dada a representatividade destes na pauta das exportações brasileiras.

Com a abertura de mercado e a redução do papel do Estado na economia brasileira, verificadas em consonância com o movimento mundial de liberação comercial, foram implementadas diversas medidas, a partir de 1990, que propiciaram aos diversos segmentos da economia nacional um aumento da eficiência produtiva. Ao invés de incentivos ou subsídios oficiais, desta vez o ganho de eficiência foi movido pela necessidade de sobrevivência no mercado. Iniciava-se uma etapa na qual o país teria uma relação fundamentalmente diferente com o mercado externo, através de uma maior integração que incluía o comércio de bens e serviços. A estratégia de integração à economia mundial exigia que as empresas brasileiras alterassem as seus sistemas de produção de forma a se adaptarem à nova conjuntura. 


\subsection{Importância do estudo}

A avicultura brasileira, desde que surgiu como atividade econômica industrializada, vem apresentando grande evolução. Os pontos cruciais que permitiram o desenvolvimento do setor avícola no Brasil são: o grande avanço tecnológico, especialmente no que diz respeito às matrizes e ao sistema produtivo utilizado, a oferta relativamente constante de alimentos, usados como insumos na atividade, e a conquista do mercado externo como alternativa para ampliação do seu mercado consumidor.

As exportações brasileiras de frango apresentaram um crescimento de $158 \%$ durante a década de 90 (Associação Brasileira de Produtores e Exportadores de Frango $\mathrm{ABEF}, 2000$ ), alcançando posição de destaque no cenário mundial. No ano de 1999 , o Brasil passa a ocupar a segunda posição na relação dos maiores produtores de frango do mundo, sendo superado apenas pelos Estados Unidos.

A avicultura tem destaque também no cenário econômico brasileiro atual. Em 1999, este setor empregou dois milhões de pessoas, movimentando US\$ 10 bilhões e gerando US\$ 875 milhões em divisas (ABEF, 2000).

Bacchi \& Spolador (2001) ${ }^{1}$ indicam que o consumo interno de carne de frango tende a crescer mais lentamente nos próximos anos devido à queda nas taxas de decréscimo dos preços observadas nos últimos tempos. Assim sendo, para que a produção de frango possa continuar crescendo da forma como vinha ocorrendo, é necessário aumentar a representatividade das exportações brasileiras no comércio internacional de aves. Torna-se importante, assim, a realização de estudos que permitam identificar as variáveis que afetam as exportações brasileiras de frangos.

\footnotetext{
${ }^{1}$ BACCH, M.R.P.; SPOLADOR, H.F.S. Elasticidade-renda do consumo físico de frango nas regiōes metropolitanas do Brasil, 2001,10 p. (Submetido à SOBER).
} 


\subsection{Objetivos}

O objetivo principal deste trabalho é estimar um modelo econométrico, fundamentado num modelo teórico, que explique a oferta de exportação brasileira de frango de forma a identificar os principais determinantes do desempenho das exportações desse setor. A principal contribuição deste estudo é fornecer embasamento para a elaboração de análises prospectivas acerca da evolução das exportações brasileiras de frango, visto que o conhecimento das variáveis condicionantes da oferta de exportação de frango sobre o quantum exportado permite, além da análise do desempenho das exportações, a simulação de políticas que visem ao desenvolvimento do referido setor. 


\section{REVISÃO DE LITERATURA}

\subsection{O mercado de frango: surgimento e consolidação da indústria avícola}

O modelo de produção avícola atual começou a se formar a partir de meados do século passado nos Estados Unidos, Europa e Japão. A necessidade de destinar carne vermelha para os soldados em combate na Segunda Guerra Mundial tornou indispensável a produção de carnes alternativas, de preferência de pequenos animais, que estivessem prontas para consumo num curto espaço de tempo. Os EUA e, no pósGuerra, os países da Europa começaram a desenvolver pesquisas no sentido de obter novas linhagens, rações e alimentos que atendessem aos requerimentos nutricionais das aves, além de desenvolver medicamentos específicos para a avicultura.

No Brasil, o aumento do consumo de carne de frango ${ }^{2}$ está relacionado à diminuição de seu preço relativo (Barros, 1994) ${ }^{3}$. Segundo Rizzi (1993), as alterações no consumo de carne de frango devem-se a algumas circunstâncias específicas. A primeira, mais importante, diz respeito ao fato de que a indústria avícola não se

\footnotetext{
${ }^{2}$ Nos anos 70, a relação de preços, em quilogramas, carne bovina/carne de frango variou entre 1,32 e 1,82 (Rizzi, 1984, p.27; extraído de Rizzi, 1993, p. 62). Nos anos 80, a partir de 1985, o preço da carne bovina esteve sempre acima do preço da carne de frango, num patamar entre 15\% e 45\% (Associação dos Produtores de Pintos de Corte - APINCO, extraído de Rizzi, 1993). Na segunda metade da década de 90 , tal relação manteve-se entre 1,59 e 2,26 (Associação Paulista de Avicultura - APA, 2001). Em relação à carne suína, também se verifica uma vantagem para a carne de frango. Dados para alguns anos selecionados mostram que, entre 1972 e 1982, o preço da carne de frango sempre esteve abaixo da carne de porco, variando entre $32 \%$ e $52 \%$, valores que permanecem inalterados se considerarmos o preço cobrado do consumidor final (Associação Brasileira de Criadores de Suínos -ABCS, 2001).

${ }^{3}$ BARROS, G.S.C. Formação de preços no setor de frangos de corte no Brasil. Piracicaba: mar. 1994. 88p. (Relatório de Pesquisa)
} 
desenvolveu apenas na escala produtiva, mas também no tocante a inovações tecnológicas do sistema produtivo. Já a produção de "outras carnes" permanece ainda, com raras exceções, relativamente atrasada em termos de processo e de matérias-primas. Tal avanço produtivo permitiu uma acentuada redução dos custos de produção e preços, além da criação de diversas variedades de produtos, permitindo a difusão e ampliação dos mercados (Rizzi, 1993).

Deve-se considerar também que sua expansão está intimamente ligada ao desenvolvimento de um mercado interno com grande potencialidade. $O$ crescimento urbano ocorrido nos anos 70 , fruto de um forte processo migratório, a participação cada vez maior da mulher no mercado de trabalho e, mais recentemente, a reestruturação da indústria alimentar, com vistas a atender às mudanças verificadas no estilo de vida do consumidor, permitiram o desenvolvimento da indústria de alimentos, especialmente da voltada à carne de frango. Santana (1999), ressaltou, em seu estudo, a ocorrência de alterações nas preferências dos consumidores associadas ao consumo de produtos de fácil preparo (prontos e semipreparados). Tais alterações, juntamente com a busca por uma dieta saudável e equilibrada, fruto da valorização de aspectos relacionados à saúde e estética, têm sido apontadas como responsáveis pelo aumento do consumo de carne de frango (Bacchi \& Spolador, op. cit.).

A Tabela 1 mostra a evolução do consumo per capita de carne de frango no Brasil entre 1970 e 2000 , que corresponde ao início efetivo da produção industrial de frango até o período recente, podendo-se verificar o expressivo aumento ocorrido. $O$ caráter industrial da produção de frango surge em meados dos anos 70 , pois até o início daquela década a maior parte da produção ocorria, ainda, em criadouros domésticos, e consolidase, no final da década de 70 (Barros, 1994).

A expansão e consolidação do complexo avícola existente atualmente podem ser explicadas por cinco pontos principais: desenvolvimento acelerado da seleção genética das aves e das rações e fontes de nutrientes para as mesmas, controle sanitário amplo e eficaz combate às doenças, avançadas técnicas de manejo e, por fim, ganhos 
tecnológicos no processamento, distribuição e comercialização do produto final. Estes cinco pontos, no conjunto, são responsáveis pelo bom desempenho da cadeia avícola brasileira.

Tabela 1. Evolução no consumo anual per capita de carne de frango no Brasil de 1970 a 2000.

\begin{tabular}{lrr}
\hline Ano & \multicolumn{1}{c}{$\mathrm{Kg}$} & Variação(\%) \\
\hline 1970 & 2,30 & \\
1975 & 4,90 & 113,04 \\
1980 & 8,70 & 77,55 \\
1985 & 8,90 & 2,30 \\
1990 & 13,60 & 6,83 \\
1991 & 14,96 & 10,00 \\
1992 & 15,74 & 5,21 \\
1993 & 17,87 & 13,53 \\
1994 & 19,06 & 6,66 \\
1995 & 23,21 & 21,77 \\
1996 & 22,05 & $-4,97$ \\
1997 & 23,83 & 8,07 \\
1998 & 23,98 & 0,63 \\
1999 & 29,14 & 21,52 \\
2000 & 29,91 & 2,64 \\
\hline
\end{tabular}

Fonte: União Brasileira de Abatedouros de Aves (UBA). extraído de Rizzi (1993) - dados referentes ao período 1970-85. Associação Brasileira de Produtores e Exportadores de Frango (ABEF).

O efetivo crescimento da produção de aves no Brasil se deu quando linhagens de matrizes desenvolvidas geneticamente foram introduzidas no país por intermédio de 
acordos comerciais. ${ }^{4}$ Essas operações de importação ocorreram até 22 de abril de 1965 , quando o Decreto n. $^{\circ} 55.981$ disciplinou a importação de matrizes para reprodução. Como conseqüência, o setor diversificou o processo produtivo, dividindo o mesmo em três categorias: granjas de matrizes avós, de pais e de pintos comerciais. Em meados da década de 70, já existiam no país dezoito empresas produtoras de matrizes avós, sendo que destas, nove eram estrangeiras. Em 1980, trinta e cinco linhagens diferentes de aves eram produzidas no país, sendo doze delas de corte (Sorj, 1982).

Torna-se importante destacar que tais números referem-se à produção de matrizes avós, o principal "subproduto" do desenvolvimento genético. Essas matrizes eram obtidas das linhagens escolhidas no processo de seleção genética e, por sua vez, originavam os reprodutores, chamados de matrizes pais, utilizados na produção dos pintos comerciais. $O$ diagrama abaixo ilustra esse processo de produção de matrizes:

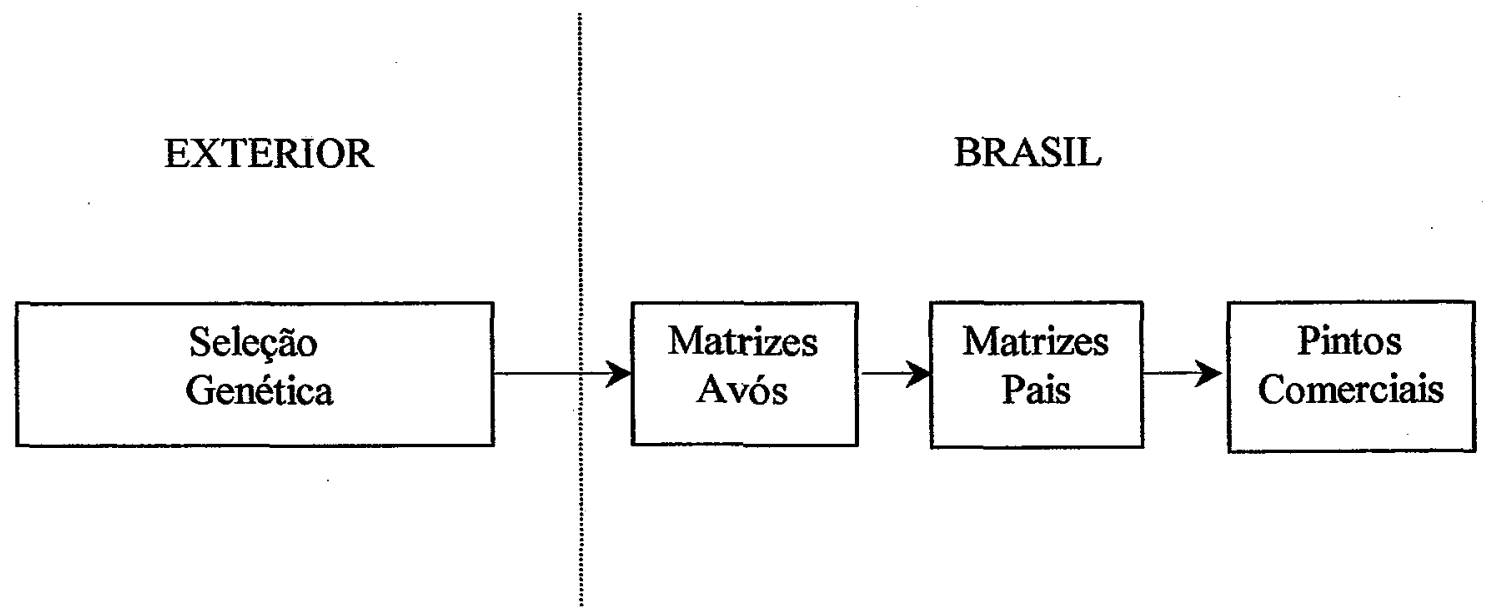

Figura 1 - Diagrama ilustrativo do processo de produção de matrizes para criação de frangos de corte no Brasil.

Fonte: Resultados da pesquisa.

Ainda hoje a seleção genética é um processo basicamente realizado no exterior, sendo desenvolvido internamente apenas seleções com monitoramento externo, ou seja,

\footnotetext{
${ }^{4}$ Em 1961, resultado de um acordo entre Robert Parks e a Granja Branca, adentraram ao país, vindo dos Estados Unidos, as primeiras matrizes importadas (Sorj, 1982).
} 
realizadas por filiais de empresas multinacionais, ou, o que é mais comum, por firmas vinculadas a grupos internacionais, que constituem empresas líderes no abate nacional. Trata-se de atividade que demanda muito capital para investimento e que pode não trazer retorno imediato, dada a lentidão do processo de seleção e a dependência de componentes genéticos muito complexos, o que exige intensa pesquisa científica, para a qual o setor público brasileiro, tampouco, conta com recursos (Barros, 1994). Outro fator inibidor do desenvolvimento da seleção genética nacional é a abundante oferta de tecnologia genética disponível no mercado internacional. A Tabela 2 apresenta as principais linhagens introduzidas no país, seus representantes $\mathrm{e}$ as respectivas participações nos mercados brasileiro e mundial.

Tabela 2. Principais linhagens de aves comercializadas, seus representantes e as respectivas participações nos mercados brasileiro e mundial - 1992.

\begin{tabular}{lllcc}
\hline Linhagens & Representantes & Origem & \multicolumn{2}{c}{ Participação (\%) } \\
& & & Brasil & Mundial \\
\hline Arbor Acres & Sadia/Pena Branca & EUA & 33 & 48 \\
Eybro $^{\text {a }}$ & & Holanda & - & 14 \\
Hubbard & Granja Rezende & Canadá & 41 & 8 \\
Roos & Agroceres & Escócia & 11 & 20 \\
Cobb & Perdigão & EUA & 7 & 10 \\
Isa & Isa do Brasil & França & 8 & - \\
Pilch & Sadia & EUA & - & - \\
\hline
\end{tabular}

Fonte: Rizzi (1993).

${ }^{a}$ Não comercializada no Brasil e sem representante, quando da pesquisa feira pelo autor.

${ }^{\mathrm{b}}$ As linhagens Isa e Pilch, juntas, representam $8 \%$ do mercado brasileiro.

As linhagens mais difundidas no mercado nacional e mundial são produzidas por empresas independentes e especializadas apenas na produção de aves geneticamente melhoradas. As demais estão vinculadas a empresas com atividades na produção de 
carne de frango. ${ }^{5}$ Em geral, as linhagens introduzidas no país, mesmo apresentando características comuns, possuem algumas diferenças básicas, cabendo ao mercado escolher dentre os tipos existentes. Tais diferenças implicam em desempenhos diversos, indicados por parâmetros de rendimento e produtividade, entre os quais destacam-se o número de pintos por fềmea e a conversão alimentar, ou seja, capacidade de transformação de alimentos em carne no menor intervalo de tempo possível. Além destes objetivos, a seleção genética busca também uniformizar o peso das aves abatidas, reduzir a taxa de mortalidade e elevar o grau de precocidade das aves.

Dentre as linhagens, a que apresenta melhor rendimento em relação ao primeiro parâmetro (pintos/fêmea) é a Hubbard - 146,00 pintos por fềmea (Rizzi, 1993). Analisando a Tabela 2, verifica-se um contraponto no tocante à participação mundial. Enquanto que no mercado mundial a linhagem Arbor Acres é predominante, no mercado brasileiro tal posição pertence à raça Hubbard. $O$ aspecto mercadológico explica esse fenômeno. A linhagem Hubbard possui certa rusticidade, apresentando estrutura óssea bem desenvolvida, além de apresentar maior tamanho e peso, o que, dadas as características do mercado interno - predominância do consumo de frango inteiro -, é desejável. Por outro lado, a Arbor Acres, segundo Rizzi (1993), é mais apropriada para os padrões de consumo dos países desenvolvidos, os quais privilegiam carnes mais elaboradas e industrializadas. As aves da linhagem Arbor Acres possuem pouca estrutura óssea e, praticamente, ausência de gordura, maximizando o rendimento em termos de carne.

O frango, dentre os animais utilizados na alimentação humana, é um dos que possuem maior capacidade de conversão alimentar (Rizzi, 1993). Para o Brasil, estimase uma relação média de conversão alimentar de $1,78 \mathrm{~kg}$ de ração para $1 \mathrm{~kg}$ de ave, ou seja, para cada $1,78 \mathrm{~kg}$ de ração obtém-se um quilograma de carne, no prazo de 41 dias.

\footnotetext{
${ }^{5}$ Segundo Rizzi (1993), a linhagem Arbor Acres pertence ao grupo Rockfeller e a Hubbard ao grupo Merck-Sharp, laboratório de produtos veterinários. A Cobb pertence à Tyson Foods, líder da indústria abatedora e, recentemente, fruto de uma associação com a Roos British Internacional. A empresa Agroceres passou a importar as bisavós e produzir internamente as avós, o que não significa a independência tecnológica.
} 
A Tabela 3 apresenta a evolução da conversão alimentar para o frango de corte no Brasil. $^{6}$

Tabela 3. Evolução da conversão alimentar obtida para o frango de corte no Brasil

\begin{tabular}{cccc}
\hline Ano & $\begin{array}{c}\text { Peso do } \\
\text { Frango }(\mathrm{g})\end{array}$ & $\begin{array}{c}\text { Conversão } \\
\text { Alimentar }\end{array}$ & $\begin{array}{c}\text { Idade } \\
\text { (Semana/Dias) }\end{array}$ \\
\hline 1930 & 1.500 & 3,50 & 15 semanas \\
1940 & 1.550 & 3,00 & 14 semanas \\
1950 & 1.800 & 2,50 & 10 semanas \\
1960 & 1.600 & 2,25 & 8 semanas \\
1970 & 1.800 & 2,00 & 7 semanas \\
1980 & 1.700 & 2,00 & 7 semanas \\
1984 & 1.860 & 1,98 & 45 dias \\
1989 & 1.940 & 1,96 & 45 dias \\
1997 & 2.250 & 1,95 & 45 dias \\
2001 & 2.240 & 1,78 & 41 dias \\
\hline
\end{tabular}

Fonte: Aves e Ovos (2001).

Profundas transformações ocorridas na estrutura produtiva agrícola brasileira nos anos 70 possibilitaram, além de mudanças na base técnica de produção, estreitamento de vínculos com as indústrias a montante e a jusante. Nesse contexto, diversos segmentos da indústria agroalimentar se modernizaram e outros, até então inexistentes, instalaramse e passaram a ter representatividade. A indústria de carnes, dentro deste contexto, apresentou grandes alterações, com a instalação de modernos frigoríficos abatedouros de aves. Dessa forma, nos anos 70, surgiu um setor moderno vinculado à política agrícola vigente - forte liquidez internacional -, mais especificamente à política de crédito subsidiado para a instalação de frigoríficos e sistemas de produção e comercialização integrados.

\footnotetext{
${ }^{6}$ A linhagem Arbor Acres, embora possua elevada conversão alimentar, por sua estrutura frágil, é mais suscetível a doenças e à mortalidade, sendo esse outro fator que explique sua pequena participação no mercado interno.
} 
O resultado desse desenvolvimento foi a intensa inserção da região Sul e do estado de São Paulo nessa avicultura moderna. Embora outros estados tenham aumentado sua participação na produção nacional, isso ocorreu através de plantas menores, voltadas, em sua maioria, para mercados regionais. Em São Paulo, a grande concentração das plantas estava relacionada ao tamanho do mercado, tanto em relação ao volume de emprego e renda gerados pela economia paulista, como por seus padrões de consumo diferenciados em relação à média nacional.

Outra questão importante quanto à industrialização ocorrida versa sobre as diferenças entre as técnicas de produção utilizadas na região Sul, principalmente em Santa Catarina, e São Paulo. Enquanto o modelo paulista estava centrado no abate do frango, sendo o fornecimento do insumo básico, o frango vivo, de responsabilidade de produtores independentes ${ }^{7}$, na região Sul o modelo de indústria avícola incluía pequenos produtores trabalhando de forma integrada (Marques, 1991). Tal modelagem, implementada primeiramente no estado de Santa Catarina, baseava-se na experiência das empresas lá estabelecidas no segmento de suínos ${ }^{8}$.

Verifica-se, assim, que a atividade avícola na região Sul constituiu-se, a priori, como uma atividade secundária dentro de um processo de diversificação da produção, tornando-se, num segundo momento, a atividade principal dessas empresas (Rizzi, 1993).

O citado "modelo catarinense" de produção integrada, similar ao verificado nos Estados Unidos da América (Zirlis et al., 1990), é definido como o grande fator de difusão de tecnologia para o setor. Considera-se que esse sistema está diretamente

\footnotetext{
${ }^{7}$ Nos anos 80, a estrutura produtiva do Sudeste é substituída pelo modelo integrado desenvolvido na região Sul (Zirlis et al., 1990).

$8 \mathrm{O}$ complexo produtivo de suínos apresenta as mesmas características verificadas para o frango. Entretanto, o consumo da carne de porco não apresentou o mesmo crescimento da carne de frango. Segundo a Associação Brasileira de Criadores de Suínos (ABCS), além do preconceito e da falta de informação, os fatores que mais dificultam o crescimento do consumo são a grande defasagem existente entre o preço do suíno na granja e o preço final no supermercado, chegando a atingir até $666 \%$ e, principalmente, o grande consumo de produtos industrializados, o que aumenta o preço final, desestimulando seu consumo. Atualmente, do total consumido no país, $30 \%$ são consumidos in natura e $70 \%$ é consumido na forma industrializada (ABCS, 2001).
} 
relacionado com o crescimento da produção e da produtividade de frango no Brasil e no mundo, pois é um sistema comum para praticamente todos os grandes produtores.

Considerando aspectos de regionalidade, o sistema de integração tem algumas variações, sendo que as principais dizem respeito ao grau de ação da empresa integradora e à liberdade do produtor dentro do processo produtivo. A integradora, no geral, é responsável pelo fornecimento do pinto e pelo pacote tecnológico, ou seja, responde pela genética das aves, ração, medicamentos, assistência técnica, além do transporte, abate e comercialização. $O$ produtor fica responsável pela parte fisica da instalação, mão-de-obra, água e energia. Os pagamentos são feitos com base no valor de mercado do produto e na produtividade dos lotes. O produtor tem ainda como fonte de receita a "cama" de frango, que é utilizada como fertilizante ou ração animal."

O principal insumo de produção da avicultura é a ração ${ }^{10}$, representando $65 \%$ dos custos do frango. A ração é utilizada durante todo o processo de produção, mas a sua representatividade na alimentação varia de acordo com a idade e propósito da ave (Barros, 1994). O desenvolvimento da indústria avícola na região Sul está "intimamente vinculado à expansão das culturas de soja e milho", insumos básicos na composição das rações animais (Rizzi, 1993, p.69). Tal caráter logístico das plantas produtivas é reforçado, atualmente, pelo crescimento da produção avícola no Centro-Oeste, área de fronteira agrícola onde há intensa produção de grãos.

O setor de ração no agronegócio brasileiro cresceu paralelamente ao desenvolvimento da avicultura. Em 1976, $72 \%$ da produção nacional de rações balanceadas era absorvida pelo setor agrícola (Giulietti et al., 1980). De acordo com estudo realizado pela Secretaria de Planejamento da Presidência da República e pelo Instituto de Pesquisa Econômica Aplicada (IPEA), em 1975, havia grande concentração

\footnotetext{
${ }^{9}$ Atualmente, dada a incidência do "mal da vaca louca", o Ministério da Agricultura proibiu a utilização da "cama" de frango na alimentação bovina. Empresas do setor estão direcionando o subproduto exclusivamente para a agricultura. A empresa Frango Sertanejo, de Guapiaçu (SP), por exemplo, está apostando na venda para lavouras anuais dos estados do Centro-Oeste e para os pomares de citros da região de São José do Rio Preto (SP), cidade próxima à indústria. (Gazeta Mercantil, 1 e 2 setembro de 2001).

${ }^{10}$ O milho representa cerca de 60 a $65 \%$ e o farelo de soja cerca de $27 \%$ na composição da ração.
} 
produtiva e geográfica no setor de fabricação de rações. A produção estava concentrada junto às unidades de produção avicola, isto é, no Sul e Sudeste do país, com predominância, embora decrescente, do estado de São Paulo. Em 1975, existiam 280 fábricas no país, sendo que 91 delas respondiam por $75 \%$ da capacidade instalada, enquanto que as 189 restantes representavam apenas $25 \%$. A tendência verificada nesse setor, de forma similar ao mercado avícola, era o desaparecimento ou a absorção das pequenas fäbricas por conglomerados maiores. As variações na oferta de matéria-prima, aliadas à defasagem tecnológica, podem ser apontadas como fatores predominantes para a ocorrência dessa concentração mercadológica ${ }^{11}$.

Outro ponto importante que colaborou para tal concentração foi o número de empresas estrangeiras ${ }^{12}$ atuando no país. Em função da larga experiência obtida em seus países de origem, tais empresas, além da instalação de modernos equipamentos de processamento, introduziram mudanças administrativas e princípios sofisticados na formulação de rações ${ }^{13}$.

O completo procesșo de verticalização proporcionou às cinco maiores empresas a duplicação da sua produção conjunta e um aumento da participação na produção nacional, passando de $17 \%$ em 1980, para $35 \%$ em 1985, posição esta mantida até 1993 , quando houve uma ligeira redução passando para $34 \%$. No final da década de 90 , as oito maiores empresas respondiam por aproximadamente $46 \%$ do total produzido. A Tabela 4 apresenta os maiores produtores de frangos no ano de 2000.

\footnotetext{
${ }^{11}$ As acentuadas oscilações dos preços do milho e do farelo de soja tornavam necessária a estocagem prolongada, além de condições para melhoria da qualidade técnica das rações.

${ }_{11}^{12}$ Dentre as empresas estrangeiras, podem ser destacadas as americanas Purina e Cargill.

${ }^{13}$ Para melhor detalhamento das inovações introduzidas, consulte Giulietti et al. (1980)
} 
Tabela 4. Maiores empresas produtoras de aves no Brasil - 2000 (milhões de aves)

\begin{tabular}{lcc}
\hline Empresas & Produção (milhões de aves) & Participação (\%) \\
\hline Sadia & 382,2 & 11,8 \\
Perdigão & 291,0 & 9,0 \\
Frangosul & 196,6 & 6,1 \\
Seara & 178,0 & 5,5 \\
Avipal & 136,6 & 4,2 \\
Pena Branca & 109,4 & 3,4 \\
DaGranja & 94,2 & 2,9 \\
Chapecó & 86,6 & 2,7 \\
Aurora & 74,2 & 2,3 \\
Sertanejo & 48,8 & 1,5 \\
Copacol & 39,2 & 1,2 \\
Rezende & 38,1 & 1,2 \\
PifPaf & 35,2 & 1,1 \\
Minuano & 35,1 & 1,1 \\
Cotrel & 31,0 & 1,0 \\
Cotrefal & 23,2 & 0,7 \\
Big Frango & 21,9 & 0,7 \\
Nicolini & 21,7 & 0,7 \\
Subtotal & $1.843,0$ & 56,8 \\
Outros & $1.401,2$ & 43,2 \\
Produção Nacional & $3.244,2$ & 100,0 \\
\hline Font ABE & As & . \\
\hline
\end{tabular}

Fonte: ABEF - Associação Brasileira de Produtores e Exportadores de Frangos.

Na década de 80, o setor apresentou uma profunda reestruturação, com a dinâmica sendo imposta pelas empresas líderes localizadas em Santa Catarina. Enquanto em São Paulo e Minas Gerais ocorria a entrada de novas firmas, ainda especializadas no abate do frango, na região Sul verificavam-se mudanças distintas. No Rio Grande do Sul, onde prevalecia ainda a especialização, a expansão se deu, basicamente, pela aquisição de algumas empresas por outras consideradas líderes em Santa Catarina. Neste 
estado, uma empresa que atuava especificamente no segmento de suínos, diversificou sua produção, abrangendo também o segmento avícola.

As três unidades produtivas restantes ampliaram sua produção através da abertura de filiais. No Paraná surgem seis novas plantas produtivas, sendo duas cooperativadas (que atuavam no setor de laticínios e suinocultura), duas independentes e duas filiais de empresas catarinenses, as quais no final da década de 80 possuíam quatro filiais operando no Paraná.

As alterações ocorridas na década de 80 não se restringiram a mudanças quantitativas. $\mathrm{O}$ período também é marcado por importantes avanços tecnológicas no processo produtivo. Essas mudanças ocorreram em dois pontos distintos: o primeiro diz respeito ao aumento na velocidade de incorporação de tecnologias no abate de aves, com maior grau de automatização, e o segundo, a novos tipos de máquinas e equipamentos usados nas fases posteriores ao abate, isto é, vinculados ao processamento de produtos recortados e industrializados (Rizzi, 1993).

Essas mudanças estão diretamente ligadas à inovação de produtos. Se nos anos 70 a produção estava centrada na obtenção de produtos homogêneos, na década seguinte, o padrão de crescimento da indústria passa a agregar novos produtos, principais elementos nas estratégias das empresas líderes. Essa tendência, por sua vez, colabora para a concentração econômica, via aquisições de empresas e diversificação em empresas correlatas.

O segmento avícola passa a atender a um mercado segmentado, através da introdução de uma gama de produtos diversificados: o frango abatido e vendido inteiro com ou sem miúdos (carcaça); o frango recortado e desossado; os produtos industrializados (apresuntado, fiambre, salsicha e mortadela); os industrializados reestruturados (hambúrguer, nugget, almôndega e lingüiça) e os produtos empanados, pré-cozidos e supergelados (coxa, sobrecoxa, tulipa, coração, asa e peito - inteiro e filé). 
Desta forma, conclui-se que a evolução e a consolidação do setor avícola no Brasil se deram através de um modelo de produção baseado em avançada tecnologia nas áreas de genética, nutrição, manejo, sanidade e equipamentos, que transformaram a avicultura numa atividade industrial bastante desenvolvida e num dos setores mais dinâmicos do agronegócio brasileiro. Outro fator que contribuiu para a consolidação do setor avícola brasileiro foi a sua inserção no mercado internacional de frango.

\subsection{Inserção do Brasil no mercado internacional de aves}

Como já discutido, foi durante a década de 70 que o setor avícola implementou o modelo de produção hoje consolidado, com grandes e pequenas empresas atuando no mercado. A ampliação da capacidade produtiva é alicerçada na demanda corrente e em projeções futuras. De outro lado, a retração da demanda gera ociosidade não planejada, o que reflete diretamente nos custos fixos médios, que, por sua vez, podem ocasionar aumento de preço. $\mathrm{Na}$ mesma direção, as decisões de investimento são influenciadas pelo passado recente; logo, períodos de maior dinamismo resultam em intensificação dos investimentos, podendo provocar um excesso de capacidade produtiva das empresas (Rizzi, 1993). Nessa linha, a redução do número de matrizes alojadas em 1975, sinalizou a existência de ociosidade não planejada, o que motivou as empresas a ajustar a produção de frango a uma demanda não realizada (Rizzi, 1993). Desta forma, a abertura de novos mercados foi de grande importância para o setor, pois, além de proporcionar a manutenção da estrutura da indústria, permitiu a entrada de novas firmas e a ampliação da capacidade produtiva das empresas líderes (Rizzi, 1993).

Nessa linha, a exportação não apenas complementou a demanda interna como se tornou importante variável para o crescimento da indústria, uma vez que as empresas líderes direcionaram parcelas significativas e crescentes de sua produção para o mercado 
externo, possibilitando que outras empresas, de menor porte, atuassem nos mercados regionais.

As exportações de frango tornaram-se, dessa forma, um importante mecanismo de ampliação do mercado e de ocupação da capacidade produtiva ociosa das empresas líderes da referida indústria, num momento em que o nível de atividade econômica apresentava redução em relação às taxas apresentadas anteriormente. $O$ crescimento das exportações verificado no período de 1975 (3.469 t) a 1980 (aproximadamente 170.000 t) representou, então, importante fator para a consolidação da estrutura da indústria de frango.

Durante a década de 80 , a queda das exportações verificadas em alguns anos foi parcialmente compensada pelo crescimento do consumo interno ocorrido principalmente na segunda metade da década, impulsionado pelos planos de estabilização econômica, principalmente o Plano Cruzado. $\mathrm{Na}$ década de 90, o crescimento foi expressivo. As exportações praticamente triplicaram, passando de $300.000 \mathrm{t}$ para aproximadamente $906.000 \mathrm{t}$ (Tabela 5). Embora a produção tenha apresentado um crescimento inferior ao das exportações, nesse período, a porcentagem da produção nacional exportada permaneceu relativamente estável, passando de 13,2\%, em 1990, para 15,2\% em 2000 . Bacchi \& Spolador, op. cit., verificaram uma redução no crescimento do consumo de frango no mercado interno nos últimos anos, ressaltando a importância do mercado externo como mecanismo importante para a manutenção/crescimento do setor avícola brasileiro. 
Tabela 5. Evolução da produção e exportação de carne de frango (inteiro e em partes) e suas respectivas participações no montante exportado pela indústria brasileira de frangos (1975/2000).

\begin{tabular}{|c|c|c|c|c|c|c|c|c|}
\hline \multirow{2}{*}{ Anos } & \multirow{2}{*}{$\begin{array}{l}\text { Produção } \\
\text { (mil ton.) } \\
\text { (A) }\end{array}$} & \multicolumn{3}{|c|}{$\begin{array}{l}\text { Exportação } \\
\text { (mil toneladas) }\end{array}$} & \multicolumn{4}{|c|}{$\begin{array}{c}\text { Participação } \\
(\%)\end{array}$} \\
\hline & & $\begin{array}{l}\text { Inteiros } \\
\text { (B) }\end{array}$ & $\begin{array}{l}\text { Partes } \\
\text { (C) }\end{array}$ & $\begin{array}{l}\text { Total } \\
\text { (D) }\end{array}$ & $\mathrm{B} / \mathrm{A}$ & $\mathrm{C} / \mathrm{A}$ & $\mathrm{D} / \mathrm{A}$ & $\mathrm{C} / \mathrm{D}$ \\
\hline 1975 & 484 & 4 & - & 4 & 0,8 & - & 0,8 & - \\
\hline 1976 & 552 & 20 & - & 20 & 3,6 & - & 3,6 & - \\
\hline 1977 & 632 & 33 & - & 33 & 5,2 & - & 5,2 & - \\
\hline 1978 & 840 & 52 & - & 52 & 6,2 & - & 6,2 & - \\
\hline 1979 & 1.019 & 81 & - & 81 & 8,0 & - & 8,0 & - \\
\hline 1980 & 1.306 & 169 & - & 169 & 12,9 & - & 12,9 & - \\
\hline 1981 & 1.490 & 294 & - & 294 & 19,7 & - & 19,7 & - \\
\hline 1982 & 1.604 & 302 & - & 302 & 18,8 & - & 18,8 & - \\
\hline 1983 & 1.584 & 289 & - & 289 & 18,3 & - & 18,3 & - \\
\hline 1984 & 1.443 & 256 & 32 & 288 & 17,7 & 2,2 & 20,0 & 11,0 \\
\hline 1985 & 1.483 & 237 & 36 & 273 & 16,0 & 2,4 & 18,4 & 13,3 \\
\hline 1986 & 1.617 & 180 & 44 & 224 & 11,2 & 2,7 & 13,9 & 19,7 \\
\hline 1987 & 1.970 & 165 & 50 & 215 & 8,4 & 2,6 & 10,9 & 23,4 \\
\hline 1988 & 1.997 & 165 & 72 & 237 & 8,3 & 3,6 & 11,9 & 30,4 \\
\hline 1989 & 2.055 & 161 & 83 & 244 & 7,8 & 4,0 & 11,9 & 33,9 \\
\hline 1990 & 2.267 & 210 & 90 & 300 & 9,2 & 4,0 & 13,2 & 29,9 \\
\hline 1991 & 2.522 & 203 & 119 & 322 & 8,1 & 4,7 & 12,8 & 36,8 \\
\hline 1992 & 2.727 & 232 & 140 & 372 & 8,5 & 5,1 & 13,6 & 37,6 \\
\hline 1993 & 3.143 & 287 & 147 & 434 & 9,1 & 4,7 & 13,8 & 33,8 \\
\hline 1994 & 3.411 & 280 & 202 & 482 & 8,2 & 5,9 & 14,1 & 41,9 \\
\hline 1995 & 4.050 & 222 & 207 & 429 & 5,5 & 5,1 & 10,6 & 48,2 \\
\hline 1996 & 4.052 & 295 & 274 & 569 & 7,3 & 6,8 & 14,0 & 48,2 \\
\hline 1997 & 4.461 & 374 & 276 & 650 & 8,4 & 6,2 & 14,6 & 42,4 \\
\hline 1998 & 4.498 & 365 & 247 & 612 & 8,1 & 5,5 & 13,6 & 40,4 \\
\hline 1999 & 5.526 & 422 & 348 & 770 & 7,6 & 6,3 & 13,9 & 45,2 \\
\hline 2000 & 5.977 & 470 & 436 & 906 & 7,9 & 7,3 & 15,2 & 48,2 \\
\hline
\end{tabular}

Fonte: ABEF - Associação Brasileira de Produtores e Exportadores de Frango. Rizzi (1993).

A Figura 2 apresenta a evolução das exportações de frango no período entre 1975 e 2000, podendo-se notar que, conforme mencionado, ocorreu grande crescimento após 
a segunda metade da década de 70, o que proporcionou ao país posição de destaque na produção e exportação mundiais.

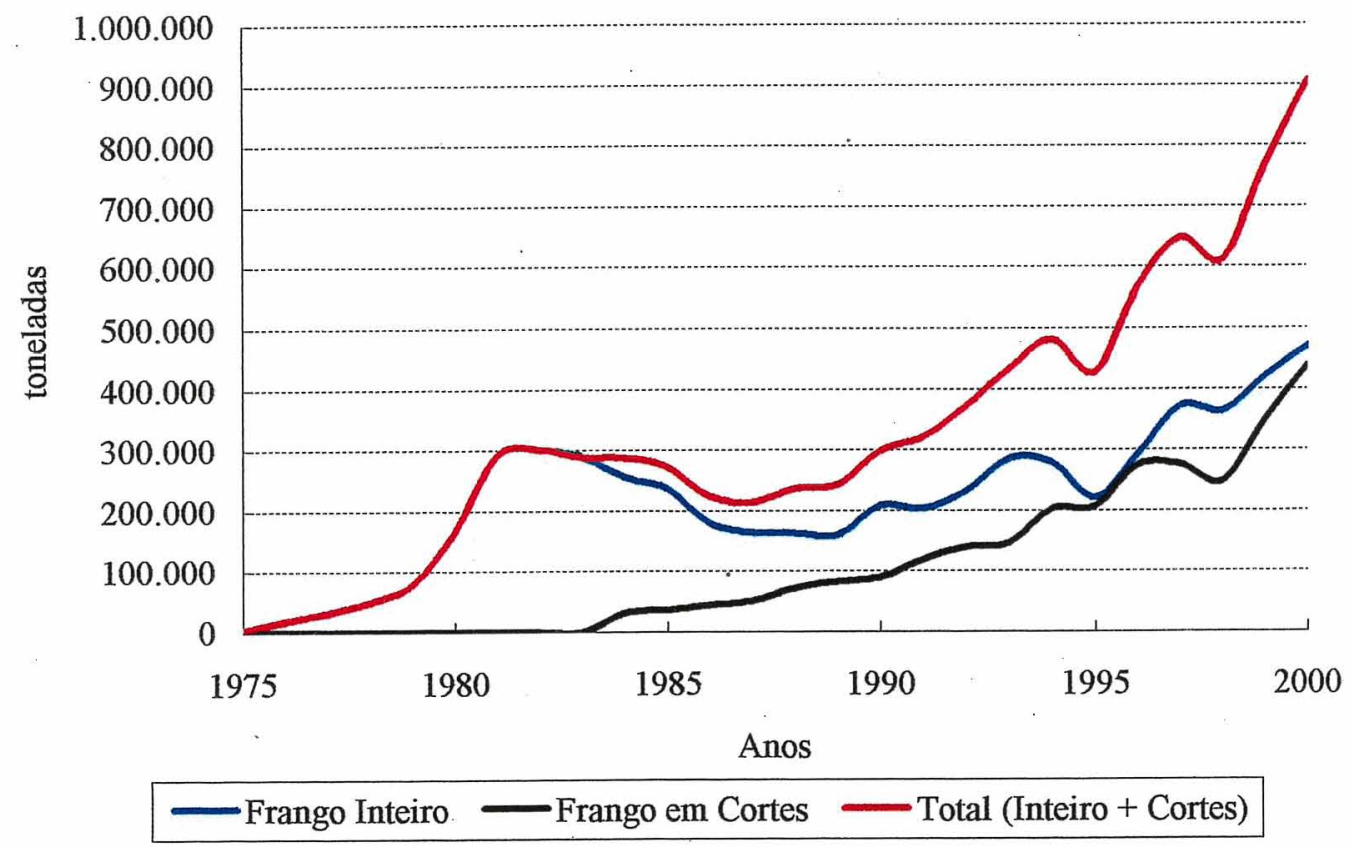

Figura 2 - Exportação brasileira de frangos - Inteiro e Cortes - 1975/2000 (toneladas).

Fonte: $\quad$ ABEF (2001).

A inserção das empresas brasileiras no mercado internacional foi fruto, de um lado, das condições tecnológicas das empresas líderes no mercado interno e, de outro, de vantagens específicas do país. Fanjzylber (1988) ${ }^{14}$, citado por Rizzi (1993), afirma que, de um modo geral, as exportações dos países em desenvolvimento são favorecidas por dotações de recursos naturais abundantes e mão-de-obra barata. No Brasil, os estímulos às exportações oferecidos pelo governo durante os anos 70 até meados dos 80 são considerados fatores importantes para consolidação das exportações brasileiras de carne

${ }^{14}$ FAJNZYLBER, F. Competitividad internacional: evolución y lecciones. Revista de la CEPAL, v.36, dez. 1988. 
de frango. Porém, o fator fundamental que permitiu o aumento das exportações relaciona-se com menores custos de produção, especificamente com mão-de-obra.

Van De Ven $(1987)^{15}$, citado por Rizzi (1993), comparou alguns custos de produção para o Brasil, França e Holanda e concluiu que os produtos brasileiros eram mais competitivos pelo fato dos baixos custos da ração e da força de trabalho compensarem o maior custo com o transporte das mercadorias. Rizzi (1993), alerta para a pouca representatividade do estudo, visto que é restrito a três países e pouco sistematizado. No entanto, conclui o autor, citando o trabalho de Fanjzylber (1988) e Furtado $(1990)^{16}$, que tais resultados são indicadores de que o Brasil possui tais vantagens $^{17}$.

De último colocado entre os dez maiores produtores em $1974^{18}$, com cerca de 2,2\% da produção mundial, o Brasil passa, em 1980, a ocupar o quinto lugar, com $3,9 \%$ do total produzido (Rizzi, $1984^{19}$, citado por Rizzi, 1993). Após uma pequena redução durante os anos de 1983-85, a produção brasileira se manteve crescente e, em 1999, o Brasil passa a ser o segundo produtor mundial, sendo responsável por $14,05 \%$ da produção total, ficando atrás apenas dos Estados Unidos (Tabela 6).

${ }^{15}$ VAN DE VEN, A.D.M. Poultry meat production in France, Brazil and the Netherlands. Revista Poultry Internacional. P.84-87, dez. 1987.

${ }^{16}$ FURTADO, J.E.M.P. Produtividade na indústria brasileira: padrões setoriais e evolução 1975/80. Campinas, 1990. 251p. Dissertação (Mestrado) - Universidade Estadual de Campinas.

${ }^{17}$ A comprovação de tais vantagens está no crescimento do volume exportado no segmento "cortes especiais", suplantando concorrentes importantes como os EUA.

${ }^{18}$ Detinham $73,6 \%$ da produção mundial.

${ }^{19}$ RIZZI, A.T. O Capital industrial e a subordinação da pequena produção agrícola: o complexo avícola no sudoeste do Paraná. Belo Horizonte, 1984. 200p. Dissertação (Mestrado) - Centro de Desenvolvimento e Planejamento Regional (CEDEPLAR), Universidade Federal de Minas Gerais. 
Tabela 6. Produção mundial de carne de frango/maiores produtores (mil toneladas)

\begin{tabular}{lrrr}
\hline País & 1997 & 1998 & 1999 \\
\hline EUA & 12.266 & 12.525 & 13.366 \\
Brasil & 4.461 & 4.875 & 5.526 \\
China & 5.200 & 5.350 & 5.500 \\
México & 1.493 & 1.587 & 1.680 \\
França & 1.212 & 1.190 & 1.180 \\
Outros & 11.885 & 11.948 & 12.080 \\
Total & 36.517 & 37.475 & 39.332 \\
\hline
\end{tabular}

Fonte: ABEF/USDA out/99.

As exportações, conforme já discutido, cresceram significativamente até 1982, passando por um período de retração e se recuperando no final da década. A redução do volume exportado na segunda metade da década de 80 pode ser explicada por alguns fatores inerentês ao comércio internacional. Primeiramente, salienta-se que o início dos anos 80 é marcado por retração das importações dos principais países capitalistas, quadro que se reverteu apenas no final daquela década. Este aspecto, aliado ao crescimento da produção de aves em alguns países, provocou uma redução do mercado potencial para o Brasil. Países do Oriente Médio, importantes mercados para a avicultura brasileira, aumentaram a produção interna e apresentaram relativa estagnação do consumo per capita.

A busca por novos mercados e a já citada reestruturação da produção, através da diversificação dos produtos, estimularam as empresas brasileiras a responder às exigências crescentes do mercado externo ${ }^{20}$, estando preparadas para atender a hábitos especificos de cada região, em termos de peso e coloração. Essas empresas desenvolveram diferentes cortes de frango, além de diferentes padrões de abate ${ }^{21}$, específicos para cada nicho de mercado. A evolução tecnológica do setor propiciou as

\footnotetext{
${ }^{20}$ Tal comportamento também se aplica ao mercado interno.

${ }^{21}$ Todo o abate que gera produto para ser exportado para os países islâmicos deve ser feito segundo as normas do "HAL.AL", supervisionado e certificado por uma entidade islâmica internacional.
} 
condições necessárias para o aproveitamento de subprodutos, que passaram a agregar valor. $\mathrm{O}$ melhor exemplo disto é o aproveitamento da desossa de dorso, costela, pescoço e outros pequenos cortes na fabricação de embutidos.

Após o período de retração das exportações na segunda metade da década de 80 , iniciou-se um crescimento ininterrupto até 1998, quando, devido à instabilidade provocada pelos mercados emergentes, ocorreu ligeira retração da quantidade exportada, prontamente recuperada no ano seguinte.

Pode-se afirmar, mesmo considerando a importância do Oriente Médio no volume brasileiro exportado, que as vendas de carne de frango têm um mercado bastante diversificado quanto ao destino, ou seja, as exportações de frango são direcionadas para inúmeros países do mundo, como mostrado na Tabela 7.

Tabela 7. Exportações brasileiras de carne de frango por destinos selecionados 1999/2000 (toneladas)

\begin{tabular}{lrrrrrr}
\hline \multirow{2}{*}{ Regiões } & \multicolumn{2}{c}{ Inteiro } & \multicolumn{2}{c}{ Cortes } & \multicolumn{2}{c}{ Total } \\
\cline { 2 - 7 } & 1999 & 2000 & 1999 & 2000 & 1999 & 2000 \\
\hline Mercosul & 45.475 & 35.816 & 6.517 & 5.769 & 51.991 & 41.585 \\
Europa & 14.851 & 23.995 & 91.069 & 135.719 & 105.920 & 159.714 \\
Oriente Médio & 315.390 & 349.127 & 20.386 & 20.665 & 335.776 & 369.792 \\
África & 12.615 & 23.100 & 9.464 & 11.980 & 22.078 & 35.080 \\
Ásia & 19.232 & 17.293 & 217.975 & 252.204 & 237.207 & 269.498 \\
A. Central & 8.568 & 7.501 & 95 & 1.718 & 8.664 & 9.219 \\
Outros & 6.210 & 13.646 & 2.705 & 8.212 & 8.915 & 21.858 \\
Total & 422.340 & 470.478 & 348.211 & 436.268 & 770.552 & 906.746 \\
\hline
\end{tabular}

Fonte: ABEF - Associação Brasileira de Exportadores de Frango (2001).

Elaborado pelo autor.

O Oriente Médio, conforme mencionado, é o principal mercado para o frango brasileiro $(40,78 \%)$, sendo predominante o consumo de frango inteiro $(94,41 \%$ do 
volume exportado para aquela região). A Ásia aparece como o segundo maior importador de frango do Brasil (29,72\%), comprando, principalmente, partes da carcaça (93,58\%), destacando-se os cortes: coxa sem osso, sobrecoxa e perna (ABEF, 2000; Gazeta Mercantil, agosto/2001). A Europa vem logo em seguida $(17,61 \%)$ e, tal qual a Ásia, sua demanda concentra-se nos cortes $(84,98 \%)$, sendo os preferidos o peito e meio-peito (ABEF, 2000). As demais regiões importam conjuntamente $11,89 \%$ do volume total exportado pelo Brasil, sendo que $74,31 \%$ deste valor refere-se a frango inteiro.

Dentre os paises importadores, destaca-se a Arábia Saudita, maior comprador de frango inteiro do Brasil (198.466 toneladas). Em 2000, os sauditas importaram cerca de $42 \%$ do total das exportações brasileiras desse produto. $O$ volume total exportado àquele país, em 2000, atingiu 207.555 toneladas, o que permite atribuir à Arábia Saudita não somente o posto de maior comprador de frango inteiro, mas também o de principal "cliente" do Brasil. É importante mencionar, porém, que o volume exportado àquele país se reduziu em 4,43\% de 1999 para 2000.

$\mathrm{Na}$ Europa, os indícios de novos casos da doença da "vaca louca" ocorridos em outubro de 2000, além do retorno da febre aftosa ao rebanho europeu no início de 2001, que afetaram negativamente a demanda por carne bovina, serviram também para aumentar o crescimento do volume exportado de frango pelo Brasil nos últimos dois anos. Naquele continente, destacam-se como importadores de frango do Brasil os Países Baixos $^{22}$, absorvendo $24,57 \%$ das exportações para lá destinadas. Em seguida, respondendo por $19,04 \%$, está a Alemanha, acompanhada de perto pelo Reino Unido $(15,37 \%)$, Espanha $(14,42 \%)$ e, mais distante, a Itália, com $4,60 \%$.

$\mathrm{Na}$ Ásia, destacam-se como principais importadores do produto brasileiro Hong Kong e Japão, com respectivamente 112.593 e $109.270 \mathrm{t}$ em 2000, absorvendo juntos $82,32 \%$ do total exportado àquela região. A doença "newcastle" no plantel chinês,

\footnotetext{
${ }^{22}$ Os dados disponibilizados pela Associação Brasileira de Produtores e Exportadores de Frango (ABEF), não indicam que o volume exportado para esses países esteja relacionado ao porto de Roterdâ, importante canal de entrada de produtos no Norte da Europa.
} 
eclodida recentemente, abre grandes possibilidades de crescimento das exportações para o continente asiático. $\mathrm{O}$ mercado filipino, recentemente aberto no extremo oriente, deve oferecer boas possibilidades de negócios para o setor avícola num futuro próximo (Gazeta Mercantil, 2001).

Outra importante região para as exportações brasileiras de carne de frango é a África, com destaque para Angola, onde a absorção das exportações brasileiras cresceu $153,35 \%$ entre 1999 e 2000 .

O crescimento das exportações para a Europa, conforme citado, tende a apresentar um certo recuo relativamente aos últimos dois anos. Os produtores brasileiros, com o objetivo de minimizar o efeito de tal retração sobre o montante exportado, estão buscando maior inserção nos novos mercados, tais como as Filipinas, Canadá e Iraque (em negociação para retomada das importações) e países da antiga União Soviética.

\subsection{Modelagem básica ${ }^{23}$}

A literatura sobre especificação e estimação de equações de oferta e demanda apresenta duas abordagens distintas: as concepções estruturais e os modelos na forma reduzida. Pode-se ilustrar ambas abordagens através do seguinte modelo:

$$
\begin{gathered}
Q=\alpha+\beta P+\gamma D \\
P=a+b Q+c S
\end{gathered}
$$

${ }^{23}$ Esta seção baseia-se em Leamer \& Stern (1970). 
no qual a equação (2.3.1) representa a função de demanda, sendo a quantidade demandada $Q$ expressa como uma função linear do preço $P$ e de algum fator deslocador da demanda $D$. Por sua vez, a oferta é expressa pela equação (2.3.2), onde o preço $P$ é uma função linear da quantidade ofertada $Q$ e de um fator deslocador da oferta $S$. As variáveis $Q$ e $P$ são endógenas enquanto que as variáveis $D$ e $S$ são exógenas. $O$ modelo descrito encontra-se em sua forma estrutural. Verifica-se que da maneira que ele foi especificado, cada variável endógena é função de uma variável exógena e da outra variável endógena do modelo. Qualquer alteração nas variáveis exógenas do modelo afetará, seqüencialmente, as variáveis endógenas do modelo. Supondo-se, por exemplo, que ocorra um acréscimo de uma unidade na variável $D$, que representa um deslocador da função de demanda, tem-se, então, uma variação de $\gamma$ unidades na quantidade demandada $Q$. Esse acréscimo irá afetar também a variável preço levando o sistema a um novo equilibrio.

Pode-se, alternativamente, expressar as variáveis endógenas como função apenas das variáveis exógenas, o que corresponde à forma reduzida do modelo, que pode ser representado por:

$$
\begin{aligned}
& Q=(1-\beta b)^{-1}(\alpha+\gamma D+\beta a+\beta c S) \\
& P=(1-\beta b)^{-1}(b \alpha+b \gamma D+a+c S)
\end{aligned}
$$

Retornando ao exemplo apresentado, verifica-se que os valores de $P$ e $Q$, correspondentes ao equilíbrio atingido após o acréscimo de uma unidade na variável $D$, podem ser diretamente obtidos através da equação (2.3.1'). Esta equação expressa a quantidade demandada, sendo que o impacto inicial $\gamma$ decorrente da variação de uma 
unidade em $D$ é multiplicado pelo fator $(1-\beta b)^{-1}$. Na equação $\left(2.3 .2^{\prime}\right)$, onde a variável dependente é o preço, o impacto inicial $\gamma$ é multiplicado pelo fator $b(1-\beta b)^{-1}$.

O sistema de equações na forma reduzida é considerado apropriado para a realização de análises prospectivas. Segundo Leamer \& Stern (1970), previsões requerem a seleção de um conjunto particular de valores para as variáveis exógenas, que, inseridas em equações na forma reduzida, permitem efetuar previsões acerca das variáveis endógenas consideradas. Adicionalmente, efeitos de política econômica podem ser obtidos diretamente através das equações na forma reduzida.

Em seguida, apresentam-se alguns dos principais estudos sobre o tema, escopo deste trabalho.

\subsection{Modelos teóricos utilizados na estimação de equações de exportação}

Apresentar-se-á, primeiramente, o modelo utilizado por Goldstein \& Khan (1978) para a estimação de equações de oferta e demanda por exportações. A apresentação desse trabalho de forma relativamente detalhada deve-se ao fato de que a metodologia proposta pelos autores é utilizada em diversos estudos de comércio exterior brasileiro, podendo-se citar os de Zini Júnior (1988), Rios (1987) e Braga \& Markwald (1983). Em seguida, apresentar-se-á alguns dos principais trabalhos encontrados na literatura brasileira acerca do assunto, destacando, em cada estudo, a metodologia utilizada.

No modelo de Goldstein \& Khan, assume-se que os produtos estrangeiros não são substitutos perfeitos para os bens domésticos. Num modelo competitivo, com custos marginais constantes, a suposição de que os bens são substitutos perfeitos implicaria na dominância de um dos mercados e em elasticidade-preço infinita. 
O objetivo primário do estudo conduzido pelos autores foi estimar as elasticidades-preço de oferta e de demanda de exportações totais de oito paises industrializados ${ }^{24}$ para o período 1955-1970. Foram estimadas as equações estruturais de oferta e demanda por exportações, obtendo-se as elasticidades para cada país considerado. Dois modelos relativamente simples de oferta e demanda de exportação foram estimados utilizando métodos de equações simultâneas, com o objetivo de eliminar qualquer viés oriundo da dupla relação existente entre preços e quantidade de exportação. No primeiro modelo utilizado pelos autores, tem-se como hipótese básica que o equilibrio é atingido de forma instantânea. No segundo modelo, denominado de "modelo de desequilibrio", admite-se a possibilidade de que o ajustamento se dê com algum atraso. Logo, a existência de excessos de oferta ou demanda, originados do desequilibrio, afeta o preço e a quantidade exportada.

a) Modelo de Equilíbrio

A demanda de exportação de determinado produto individual pode ser representada utilizando-se uma especificação log-linear como segue:

$$
\log X_{t}^{d}=a_{0}+a_{1} \log \left(P X_{t} / P X W_{t}\right)+a_{2} \log Y W_{t}
$$

sendo:

\footnotetext{
${ }^{24}$ Os países analisados são: Bélgica, França, Alemanha, Itália, Japão, Holanda, Reino Unido e Estados Unidos.
} 
$X^{d} \quad$ a quantidade demandada de exportação;

$P X \quad$ o preço das exportações sob a ótica dos importadores;

PXW a média ponderada dos preços das exportações dos parceiros comerciais do país importador (produtos substitutos);

IW a média ponderada das rendas reais dos parceiros comerciais do país exportador.

Como a equação (2.4.1) é especificada em logaritmos, $a_{1}$ e $a_{2}$ são, respectivamente, as elasticidade-preço (relativo) e elasticidade-renda (real) da demanda de exportação. Espera-se que o valor de $a_{1}$ seja negativo e $a_{2}$ seja positivo ${ }^{25}$.

Por sua vez, a oferta de exportação, também especificada como uma função loglinear, é expressa em função do preço relativo das exportações (preço das exportações em relação ao preço doméstico) e de um índice representativo da capacidade produtiva do país exportador:

$$
\log X_{t}^{s}=\beta_{0}+\beta_{1} \log \left(P X_{t} / P_{t}\right)+\beta_{2} \log Y_{t}^{*}
$$

sendo:

$X^{s} \quad$ a quantidade ofertada para exportação;

$P X \quad$ o preço das exportações medido em moeda do país exportador;

$P \quad$ preço doméstico;

$Y^{*} \quad$ a capacidade produtiva doméstica (produto potencial).

${ }^{25} \mathrm{O}$ sinal da elasticidade-renda (real) pode ser negativo se as exportações forem dependentes de uma demanda residual do resto do mundo. Isso significa que um aumento na renda mundial implicará num aumento das produções domésticas, impactando negativamente as exportações. 
A equação (2.4.2) incorpora a premissa de que se o preço das exportações aumenta relativamente ao preço doméstico, a produção destinada à exportação se torna mais lucrativa e, por conseguinte, os exportadores aumentarão a oferta para exportação. Adicionalmente, considera-se que, coeteris paribus, há uma relação positiva entre a capacidade produtiva doméstica e a oferta de exportações. Dessa forma, espera-se que os coeficientes $\beta_{1}$ e $\beta_{2}$ sejam positivos. A equação (2.4.2) pode ser normalizada para variável preço das exportações, $P X_{t}$, obtendo-se:

$$
\log P X_{t}=b_{0}+b_{1} \log X_{t}^{s}+b_{2} \log Y_{t}^{*}+b_{3} \log P_{t}
$$

sendo:

$$
b_{0}=-\frac{\beta_{0}}{\beta_{1}} ; b_{1}=\frac{1}{\beta_{1}} ; b_{2}=-\frac{\beta_{2}}{\beta_{1}} \text { e } b_{3}=\frac{\beta_{1}}{\beta_{1}}
$$

Como $\beta_{1}, \beta_{2}>0$, espera-se que $b_{1}, b_{3}>0$ e $b_{2}<0$.

Dessa forma, o modelo de equilibrio, como definido pelos autores, é representado pelas equações (2.4.1) e (2.4.3), e a estimação dos parâmetros estruturais pode ser feita através de metodologia apropriada para a estimação de equações simultâneas ${ }^{26}$. Com o objetivo de avaliar os efeitos das variáveis exógenas somente, os autores obtêm as formas reduzidas de ambas as equações:

$\log X_{t}=\frac{a_{0}+a_{1} b_{0}}{1-a_{1} b_{1}}-\frac{a_{1}}{1-a_{1} b_{1}} \log P X W_{t}+\frac{a_{2}}{1-a_{1} b_{1}} \log Y W_{t}+\frac{a_{1} b_{2}}{1-a_{1} b_{1}} Y_{t}^{*}+$

\footnotetext{
${ }^{26}$ Assume-se $X_{t}^{s}=X_{t}^{d}=X_{t}$, além da adição dos termos erráticos. Os autores argumentam que o mercado se ajusta instantaneamente.
} 


$$
+\frac{a_{1} b_{3}}{1-a_{1} b_{1}} \log P_{t}
$$

$\log P X_{t}=\frac{b_{0}+a_{0} b_{1}}{1-a_{1} b_{1}}-\frac{a_{1} b_{1}}{1-a_{1} b_{1}} \log P X W_{t}+\frac{a_{2} b_{1}}{1-a_{1} b_{1}} \log Y W_{t}+\frac{b_{2}}{1-a_{1} b_{1}} Y_{t}^{*}+\frac{b_{3}}{1-a_{1} b_{1}} \log P_{t}$

considerando que $1-a_{1} b_{1}>0$, espera-se que os coeficientes das formas reduzidas apresentem os seguintes sinais especificados na Tabela 8:

Tabela 8. Coeficientes das equações na forma reduzida do modelo de equilibrio.

\begin{tabular}{lcccc} 
& $\log P X W$ & $\log Y W_{t}$ & $Y_{t}^{*}$ & $\log P$ \\
\hline $\log X_{t}$ & + & + & + & - \\
$\log P X_{t}$ & + & + & - & + \\
\hline
\end{tabular}

Fonte: Goldstein \& Khan (1978).

b) Modelo de Desequilíbrio 
Os autores utilizam o mecanismo de ajustamento desenvolvido por Houthakker \& Taylor $(1970)^{27}$ para explicar a existência de desequilíbrio no mercado. No modelo de desequilibrio, assume-se que as exportações se ajustam entre dois períodos em uma proporção da diferença existente entre a demanda de exportação no período $t$ e o fluxo do período anterior:

$$
\Delta \log X_{t}=\gamma\left\lfloor\log X_{t}^{d}-\log X_{t-1}\right\rfloor
$$

sendo $\gamma$ o coeficiente de ajustamento, positivo, e $\Delta$ o operador de primeira diferença. ${ }^{28}$

$\mathrm{Na}$ equação (2.4.6) fica explícito que a quantidade exportada se ajusta entre dois períodos em decorrência do excesso de demanda existente no resto do mundo.

Substituindo a equação (2.4.1) em (2.4.6), tem-se:

$$
\log X_{t}=c_{0}+c_{1} \log \left(P X_{t} / P X W_{t}\right)+c_{2} \log Y W_{t}+c_{3} \log X_{t-1}
$$

sendo $c_{0}=\gamma a_{0}, c_{1}=\gamma a_{1}, c_{2}=\gamma a_{2}$, e $c_{3}=1-\gamma$. Baseado nos sinais esperados dos parâmetros $a_{1}, a_{2}$ e $\gamma$, espera-se que: $c_{1}<0, c_{2}>0$ e $c_{3}>0$.

Da mesma forma que a quantidade exportada se ajusta por excesso de demanda, o preço das exportações se ajusta por excesso de oferta:

$$
\left.\Delta \log P X_{t}=\lambda \mid \log X_{t}-\log X_{t}^{s}\right\rfloor
$$

${ }^{27}$ HOUTHAKKER, H.S.; TAYLOR, L.D. Consumer demand in the United States. 2.ed. Cambridge: Harvard University Press, 1970.

${ }^{28} \Delta \log X_{t}=\log X_{t}-\log X_{t-1}$ 
sendo $\lambda$ o coeficiente de ajustamento, considerado como positivo. Nessa estrutura, um aumento no excesso de oferta implicará na diminuição do preço das exportações e viceversa.

Substituindo a equação (2.4.2) em (2.4.8) e resolvendo para $\log P X_{t}$, obtém-se:

$$
\log P X_{t}=d_{0}+d_{1} \log X_{t}+d_{2} \log P_{t}+d_{3} \log Y_{t}^{*}+d_{4} \log P X_{t-1}
$$

sendo:

$$
d_{0}=\frac{-\lambda \beta_{0}}{1+\lambda \beta_{1}}, d_{1}=\frac{\lambda}{1+\lambda \beta_{1}}, d_{2}=\frac{\lambda \beta_{1}}{1+\lambda \beta_{1}}, d_{3}=\frac{-\lambda \beta_{2}}{1+\lambda \beta_{1}} \mathrm{e} d_{4}=\frac{1}{1+\lambda \beta_{1}}
$$

Como $\beta_{1}>0, \beta_{2}>0$ e $\lambda>0$, espera-se que $d_{1}, d_{2}, d_{4}>0$ e $d_{3}<0$.

Por fim, as formas reduzidas para o modelo de "desequilibrio" são obtidas das equações (2.4.7) e (2.4.9):

$$
\begin{aligned}
\log X_{t}= & \frac{c_{0}+c_{1} d_{0}}{1-c_{1} d_{1}}-\frac{c_{1}}{1-c_{1} d_{1}} \log P X W_{t}+\frac{c_{2}}{1-c_{1} d_{1}} \log Y W_{t}+\frac{c_{1} d_{3}}{1-c_{1} d_{1}} \log Y_{t}^{*}+ \\
& +\frac{c_{1} d_{2}}{1-c_{1} d_{1}} \log P_{t}+\frac{c_{1} d_{4}}{1-c_{1} d_{1}} \log P X_{t-1}+\frac{c_{3}}{1-c_{1} d_{1}} \log X_{t-1}
\end{aligned}
$$

$\log P X_{t}=\frac{d_{0}+d_{1} c_{0}}{1-c_{1} d_{1}}-\frac{c_{1} d_{1}}{1-c_{1} d_{1}} \log P X W_{t}+\frac{c_{2} d_{1}}{1-c_{1} d_{1}} \log Y W_{t}+\frac{d_{3}}{1-c_{1} d_{1}} \log Y_{t}^{*}+$ 


$$
+\frac{d_{2}}{1-c_{1} d_{1}} \log P_{t}+\frac{d_{4}}{1-c_{1} d_{1}} \log P X_{t-1}+\frac{c_{3} d_{1}}{1-c_{1} d_{1}} \log X_{t-1}
$$

Espera-se que os sinais dos coeficientes das equações na forma reduzida, dados os sinais dos parâmetros estruturais, sejam os apresentados na Tabela 9:

Tabela 9. Coeficientes das equações na forma reduzida do modelo de desequilibrio.

\begin{tabular}{lcccccc}
\hline & $\log P X W_{t}$ & $\log Y W_{t}$ & $\log Y_{t}^{*}$ & $\log P_{t}$ & $\log P X_{t-1}$ & $\log X_{t-1}$ \\
\hline $\log X_{t}$ & + & + & + & - & - & + \\
$\log P X_{t}$ & + & + & - & + & + & + \\
\hline
\end{tabular}

Fonte: Goldstein \& Khan (1978)

Para estimação dos modelos acima descritos, os autores utilizaram o método de Máxima Verossimilhança de Informação Plena (FIML) ${ }^{29}$, considerado o melhor estimador pela teoria assintótica, embora seja muito sensível a alterações nas especificações ou nos dados (Goldstein \& Khan, 1978).

Segundo Zini Júnior (1988), a literatura sobre especificação e estimação de equações de comércio exterior apresenta dois enfoques tradicionais: o modelo para economia pequena e o modelo competitivo de dois países. O primeiro enfoque utiliza a hipótese de que o país em questão possui uma participação pequena no total de exportações e importações mundiais. Assim sendo, essa economia se depara com uma função de oferta de importação e uma de demanda de exportação infinitamente preço-

\footnotetext{
${ }^{29}$ Para o Japão, os autores utilizaram o método de Mínimos Quadrados em Dois Estágios (2SLS)
} 
elástica ou com elasticidade alta $^{30}$. Na segunda estrutura, que considera um modelo competitivo entre dois países, as hipóteses sobre elasticidades infinitas são removidas e, tanto o volume quanto o preço do comércio entre os mesmos são explicados por meio de quatro funções: a oferta e a demanda de exportação e a oferta e demanda de importação. As relações preço-quantidade existentes nas teorias do consumidor e da produção são as bases para a especificação dessas funções. Ambos os modelos, de Zini Júnior (1988) e de Goldstein \& Khan (1978), são variações condizentes com a segunda estrutura apresentada.

Em seu estudo, Zini Júnior (1988) especifica equações de oferta e demanda de exportação e por importação, mas seguindo o escopo deste trabalho, apresentar-se-á apenas a especificação do modelo de exportação. No modelo apresentado pelo autor para a análise do comportamento das exportações, tem-se como pressuposição que os produtos importados não são substitutos perfeitos para os bens domésticos. Esse pressuposto parece ser compatível com o que se tem observado na prática em termos de comércio internacional, justificando a adoção da hipótese de substituição imperfeita ${ }^{31}$. Tal qual no trabalho apresentado anteriormente, o autor constrói dois modelos que explicam as exportações, um modelo de equilibrio e um de desequilíbrio.

As funções de oferta e demanda de exportação podem ser apresentadas utilizando-se uma especificação log-linear, como segue:

$$
\ln X_{t}^{d}=a_{11}+a_{12} \ln \left(P X_{t} / P X W_{t}\right)+a_{13} \ln Y W_{t}+u_{1 t}
$$

sendo:

$X^{d} \quad$ a quantidade demandada de exportação;

$P X \quad$ o preço das exportações;

${ }^{30}$ Carvalho \& Negri, 2000 também fazem tal referência.

${ }^{31}$ MAGEE, S. Prices, income and foreign trade: a survey of recent economic studies. In: KENEN, P.B. (ed.) International Trade and Finance: frontiers for research. Cambridge: Cambridge University Press, 1975. p. 175-252. 
$P X W$ o preço dos bens substitutos do resto do mundo;

$Y W \quad$ a renda real no resto do mundo;

$u_{1} \quad$ distúrbio aleatório com média zero, variância constante e não correlacionado à variável exógena

Por sua vez, a oferta de exportação, também especificada como uma função loglinear, é expressa em função do preço relativo das exportações, da capacidade produtiva do país exportador e de índice de ciclos da economia doméstica:

$$
\ln X_{t}^{s}=b_{11}+b_{12} \ln \left(e_{t} P X_{t} S_{t} / P D_{t}\right)+b_{13} \ln Y T_{t}+b_{14} \ln U_{t}+u_{2 t}
$$

sendo:

$X^{s}$ a quantidade ofertada de exportação;

$e$ a taxa nominal de câmbio;

$P X \quad$ o preço das exportações;

$S$ a taxa média de subsídios;

$P D$ o preço doméstico;

YT a capacidade produtiva doméstica (produto potencial);

$U$ o índice de ciclos domésticos (utilização da capacidade instalada);

$u_{2}$ distúrbio aleatório com média zero, variância constante, não correlacionado com a variável exógena

Segundo o autor, o índice de preço doméstico, $P D$, apresenta duplo papel na função de oferta de exportação. Supondo um dado nível de preço para as exportações, a rentabilidade de produzir bens exportáveis cai à medida que os custos domésticos aumentam, $P D$ seria, então, uma proxy para tais custos. Adicionalmente, quando $P D$ sobe relativamente, a rentabilidade de vender para o mercado externo diminui, afetando negativamente a oferta de exportações. Pode-se afirmar, assim, que $b_{12}$ possui sinal negativo. 
Zini Júnior (1988) alega que, sob padrões normais de comércio, o sinal esperado de $b_{13}$, coeficiente da variável capacidade produtiva doméstica, é positivo, pois, conforme cresce a capacidade produtiva, cresce a oferta para os mercados doméstico e externo. Em relação à magnitude, o coeficiente pode ser maior que a unidade (indicando um viés pró-comércio), unitário (neutralidade sobre as exportações), menor que a unidade (viés anticomercial fraco) ou ainda, negativo (viés anticomercial forte).

A inclusão de uma variável para os ciclos na economia doméstica $(U)$ se dá, segundo o autor, captar os efeitos dos ciclos de demanda interna sobre a oferta de exportação. Existe a premissa de que os produtores, durante períodos de crescimento da economia, preferem atender à demanda doméstica, preservando assim sua participação nesse mercado. Alguns autores afirmam que os produtores brasileiros buscam o mercado externo apenas como forma de vender sua produção excedente.

Zini Júnior (1988), opta por estimar o modelo formado pelas equações acima especificadas pelo método de Mínimos Quadrados em Dois Estágios (2SLS). A escolha do método de Mínimos Quadrados em Dois Estágios (2SLS), segundo o autor, torna menos relevante o estudo do problema de identificação correta do sistema, visto que os outros métodos aplicáveis, Máxima Verossimilhança de Informação Plena (FIML) e Mínimos Quadrados em Três Estágios (3SLS), são considerados mais eficientes apenas para modelos corretamente especificados.

Outro aspecto interessante abordado por Zini Júnior (1988) diz respeito à taxa de câmbio real e seu impacto sobre o comércio exterior brasileiro. Dessa forma, o autor decompõe o preço relativo da seguinte forma:

$$
\ln \left(e_{t} P X_{t} S_{t} / P D_{t}\right)=\ln \left(e_{t} P W W_{t} / P W D_{t}\right)+\ln \left(P X_{t} / P W W_{t}\right)-\ln \left(P D_{t} / P W D_{t}\right)+\ln \left(S_{t}\right)
$$

sendo: 
$P W W \quad$ o índice de preço por atacado no resto do mundo;

PWD o índice de preço por atacado doméstico; e as demais variáveis já definidas .

Os termos do lado direito de (2.4.14) são, respectivamente, a taxa de câmbio real, o preço real das exportações no mercado externo, o preço real das exportações no mercado doméstico e a taxa de subsídios. Permitindo-se respostas diferentes para cada uma delas, reescreve-se a equação (2.4.13) como:

$$
\begin{aligned}
\ln X_{t}^{s} & =b_{21}+b_{22} \ln \left(e_{t} P W W_{t} S_{t} / P W D_{t}\right)+b_{23} \ln \left(P X_{t} / P W W_{t}\right)+b_{24} \ln \left(P D_{t} / P W D_{t}\right)+ \\
& +b_{25} \ln S_{t}+b_{26} Y T_{t}+b_{27} \ln U_{t}+u_{3 t}
\end{aligned}
$$

sendo $u_{3}$ um termo de distúrbio aleatório.

Substituindo a quantidade desejada pela quantidade observada nas equações, tem-se um modelo de equilíbrio de comércio, considerando que os ajustamentos ocorram de forma instantânea.

A existência de contratos de longo prazo, de informação imperfeita e de custos de adaptação conduz ao questionamento desse ajuste instantâneo, pois se torna plausivel que tais ajustamentos levem certo tempo para ocorrer em sua totalidade. Para tais casos, deve-se incorporar algum mecanismo dinâmico de resposta, principalmente para os casos onde a freqüência dos dados é grande. Os modelos que incorporam tais características são conhecidos como modelos de desequilíbrio, já discutidos quando da apresentação do estudo de Goldstein \& Khan (1978).

Zini Júnior (1988) introduz dinâmica no sistema de equações considerando um modelo com ajustamento parcial, ou seja, inclui-se uma variável dependente defasada do lado direito das equações (2.4.12) e (2.4.13). Tal modelo, de ajustamento parcial, é um caso particular do modelo geral de defasagens distribuídas com pesos declinando 
geometricamente, conhecido como modelo de "Koyck". Considera-se que a oferta e a demanda se ajustem com uma defasagem da seguinte forma:

$$
\begin{aligned}
& \ln X_{t}-\ln X_{t-1}=d_{1}\left(\ln X_{t}^{d}-\ln X_{t-1}\right) \\
& \ln X_{t}-\ln X_{t-1}=d_{2}\left(\ln X_{t}^{s}-\ln X_{t-1}\right)
\end{aligned}
$$

sendo $d_{1}$ e $d_{2}$ coeficientes de ajustamento $\left(0<d_{i}<1\right)$.

Substituindo (2.4.12) e (2.4.13) em (2.4.16) (2.4.17), têm-se após a reparametrização:

$$
\begin{gathered}
\ln X_{t}^{d}=a_{31}+a_{32} \ln \left(P X_{t} / P X W_{t}\right)+a_{33} \ln Y W_{t}+a_{34} \ln X_{t-1}+u_{4 t} \\
\ln X_{t}^{s}=b_{31}+b_{32} \ln \left(e_{t} P X_{t} S_{t} / P D_{t}\right)+b_{33} \ln Y T_{t}+b_{34} \ln U_{t}+b_{35} \ln X_{t-1}+u_{5 t}
\end{gathered}
$$

Esse mecanismo de ajustamento parcial pode também ser utilizado na equação (2.4.14) especificada para obter a elasticidade em relação à taxa de câmbio real.

O modelo de ajustamento parcial permite que se obtenham as elasticidades de curto e longo prazo, sendo as elasticidades de curto prazo os próprios parâmetros estimados na regressão e, as elasticidades de longo prazo, os resultados da operação que consiste da divisão destes parâmetros pelo respectivo coeficiente de ajustamento.

Braga \& Markwald (1983) estimaram um modelo de oferta e demanda por exportações de produtos manufaturados com base em séries anuais dos anos de 1959/81 utilizando o método de equações simultâneas. $O$ referido trabalho utiliza a mesma estrutura teórica apresentada em Goldstein \& Khan (1978). Os autores apresentaram uma extensa resenha crítica da literatura correlata, visando a sistematizar as tentativas 
precedentes e indicar suas limitações. Visto que a estrutura teórica desenvolvida por Goldstein \& Khan já foi apresentada, limita-se aqui a expor aquilo que se considera como efetiva contribuição do estudo, ou seja, suas considerações acerca dos trabalhos existentes na literatura.

Entre os estudos examinados pelos autores, encontram-se os de Doellinger et al. (1971), o de Markwald (1981) e o de Mussi (1982). ${ }^{32}$ Os autores destacam que particularidades existentes nos trabalhos no tocante à periodicidade das observações, critério de agregação dos dados, mensuração da variável dependente etc. inviabilizam a comparação dos resultados obtidos. Dessa forma, o estudo busca discutir as diferentes abordagens metodológicas, destacando as diferentes opções de escolha do modelo econométrico e do método de estimação, formas funcionais, definição da variável dependente e a seleção de variáveis explicativas.

Segundo os autores, não havia, dentre os estudos econométricos sobre oferta e demanda de exportações de manufaturados no Brasil, nenhuma tentativa de estimação do modelo em sua forma estrutural através de métodos próprios para equações simultâneas. Os seguintes procedimentos eram adotados: i) estimações de equações de oferta, sob a hipótese de país pequeno e demanda infinitamente elástica; ii) estimações de equações de oferta e demanda efetuadas separadamente (métodos não-sistêmicos) e, por fim, iii) estimações de formas reduzidas de modelos estruturais, que freqüentemente são desconhecidos, implicando na estimação de formas reduzidas ad hoc.

Contrariamente à facilidade de operacionalização e sua aparente evidência (no caso de produtos manufaturados - que representam pequena porção do mercado mundial), a hipótese de "país pequeno" impossibilita a análise dos efeitos da renda mundial sobre as exportações, pois, mantida a hipótese, a análise se reduz a uma

\footnotetext{
${ }^{32}$ DOELLINGER, C. et al. Exportações dinâmicas brasileiras. Rio de Janeiro: Instituto de Planejamento Econômico e Social.(IPEA/INPES), 1971. 194p. (Coleção Relatórios de Pesquisa, 2)

MARKWALD, R.A. Estimação de equações de oferta desagregadas para o Brasil, 1960-1980. Rio de Janeiro: IPEA/INPES, 1981. (Coleção Relatórios de Pesquisa)

MUSSI, C.H.F. Fatores de demanda nas exportações de manufaturados brasileiros. Rio de Janeiro, 1982.

Dissertação (Mestrado) - Pontifícia Universidade Católica.
} 
equação estrutural de oferta que capta todas as alterações oriundas do lado da demanda através da variável preço. As formas reduzidas, especificadas sob os critérios ad hoc, são criticadas pela ausência de um modelo estrutural que possibilite a definição correta e precisa das equações. Nesse sentido, os autores destacam a importância da correta identificação do modelo estrutural que serviu de base para a obtenção da forma reduzida. Por fim, a estimação por métodos uniequacionais, embora seja uma aproximação ao problema, conduz a estimadores inferiores àqueles obtidos por métodos sistêmicos.

Em relação à especificação da forma funcional, todos os estudos apreciados pelos autores apresentavam equações na forma log-linear. Os autores tecem severas críticas aos textos consultados por não tratarem do problema de escolha da forma funcional, excetuando o trabalho de Reis $(1979)^{33}$, no qual encontram-se, além de comparações entre as formas linear e log-linear, pequena nota sobre o teste de Sargan que, embora não rigoroso, auxilia na escolha entre as formas linear e log-linear. A principal opção da literatura pela forma log-linear reside no fato de que as elasticidades são obtidas diretamente dos resultados da regressão e, diferentemente das formas lineares, são constantes e independem dos valores assumidos pelas variáveis.

Os autores procuraram classificar as variáveis explicativas utilizadas nos modelos dos estudos analisados, distribuindo as variáveis da seguinte maneira: a) variáveis que captam o efeito preço; b) variáveis que captam o efeito renda externa; c) variáveis que captam algum efeito tendencial; d) variáveis que captam os ciclos e, por fim, e) variáveis que captam defasagens ou custos de ajustamento.

As variáveis utilizadas na literatura para captar o efeito preço são, segundo os autores, a taxa de câmbio nominal, os preços externos, os preços domésticos e um índice de subsídios. São comumente reunidas sob a forma de uma variável composta:

\footnotetext{
${ }^{33}$ REIS, E.J. Estimação de equações de exportações. Rio de Janeiro: IPEA/INPES, 1979.
} 


$$
E \cdot P^{*}(1+s) / P \text { ou } E \cdot P^{*} / P(1-s)
$$

sendo:

$$
\begin{array}{ll}
E & \text { a taxa de câmbio nominal; } \\
P & \text { o índice de preços domésticos; } \\
P^{*} & \text { o índice de preços externos; } \\
S & \text { a taxa de subsídios. }
\end{array}
$$

Somente no trabalho de Paula Pinto (1983), segundo os autores, há separação do efeito preço em elasticidades-preço de oferta e de demanda de exportação, sendo que a primeira é incorporada para captar a lucratividade do exportador e a segunda é incorporada como um preço relativo representativo da competitividade das exportações, com a forma:

$$
P^{*} / P W
$$

sendo:

$P^{*} \quad$ O índice de preço das exportações de manufaturados brasileiros em dólares;

$P W \quad \mathrm{O}$ índice ponderado de preço das exportações de manufaturados de outros países em dólares.

As variáveis que captam o efeito renda externa são incluídas nos modelos que admitem a existência de uma demanda não-perfeitamente elástica. Nesses casos, a renda externa surge como variável explicativa na equação de demanda de exportação e busca captar o efeito "tamanho do mercado", ou seja, mensurar qual o efeito de um crescimento (ou uma recessão) mundial sobre as exportações. Relatam os autores, a existência de trabalhos nos quais existe a preocupação de selecionar os principais 
parceiros comerciais do país e introduzir um sistema de ponderações para construir um índice representativo da renda externa.

A implantação do Plano Real, em julho de 1994, e a combinação de fatores como estabilidade da moeda, valorização da taxa de câmbio nominal, a utilização das importações como forma de controle de preços domésticos e os sucessivos déficits da balança comercial despertaram o interesse sobre o comportamento das exportações e importações brasileiras. Diversos estudos foram feitos, sendo alguns deles relacionados à exportação, discutidos a seguir.

Castro \& Cavalcanti (1997) estimaram equações de exportação e importação para o Brasil, para o período 1955/95, com o objetivo de realizar previsões condicionais à evolução futura das variáveis determinantes das exportações, obtendo, dessa forma, subsídios para o processo de formulação, implementação e avaliação de políticas econômicas.

Foram estimadas, a partir de dados anuais, equações para as exportações e importações totais e desagregadas (por fator agregado e categorias de uso, respectivamente). Apesar da utilização de índices de preço e quantum ser preferível do ponto de vista teórico, os autores optaram por utilizar séries originais. Essa escolha deve-se ao fato de que os resultados obtidos são diretamente aplicáveis à análise da balança comercial do país.

As equações formuladas para analisar o comportamento das exportações brasileiras consideraram como variáveis explicativas a taxa de câmbio real, uma proxy para o nível de renda mundial e um indicador de atividade doméstica. A taxa de câmbio real foi obtida pelos autores através da multiplicação da taxa de câmbio nominal por um índice de incentivos às exportações e pelo IPA norte-americano, dividido pelo IPA doméstico. Como proxy para a renda mundial, utilizou-se o índice das importações mundiais totais, em valor real e, por fim, a taxa de utilização da capacidade produtiva total, obtida pela razão entre o PIB e o produto potencial da economia, foi aplicada como indicador do nível de atividade doméstica. 
As análises das exportações totais e desagregadas por fator agregado (produtos manufaturados, semimanufaturados e básicos) baseiam-se, inicialmente, em modelos VAR (Auto-Regressão Vetorial) com três defasagens das variáveis explicativas pertinentes, sendo, posteriormente, ajustado o número de defasagens a ser utilizado. Para a análise das exportações de produtos básicos, o autor utilizou um modelo VAR com três defasagens considerando as variáveis exportação de produtos básicos, taxa de câmbio e importações mundiais. Incluíram-se, ainda, dummies para os anos de 1962, 1972/73 e 1986. A inclusão dessas variáveis dummies deve-se, segundo os autores, à dificuldade de modelar adequadamente o comportamento das exportações de produtos básicos, dadas as mudanças bruscas de preço e quantidade, inerentes aos mercados envolvidos. O processo de redução do modelo conduziu a um VAR com uma defasagem.

Cavalcanti \& Ribeiro (1998) buscaram analisar a evolução das exportações brasileiras no período 1977/96, destacando os acontecimentos dos anos 90 e, adicionalmente, e identificar os principais determinantes do desempenho exportador através da estimação de equações de exportação. As primeiras seções do estudo tratam: a) da importância das exportações no ajuste externo, destacando as alterações no modelo macroeconômico vigente, passando de um modelo no qual o Estado era o principal agente do crescimento (ativo ou passivo) e o mercado doméstico fortemente protegido da concorrência externa (por mecanismos tarifários e não-tarifários), para um modelo em que a participação do Estado na economia é mínima e os mercados abertos à concorrência externa; b) do desempenho histórico das exportações brasileiras, em três fases distintas, 1955/96, 1977/96 e década de 90, analisando o comportamento das variáveis que pudessem explicar tal performance ${ }^{34}$.

Segundo os autores, a especificação de um modelo de exportações segue três linhas básicas. A primeira considera a hipótese de país pequeno, sendo que as exportações do país analisado constituem parcela muito pequena do comércio mundial,

\footnotetext{
${ }^{34}$ Para maior aprofundamento, consultar Cavalcanti \& Ribeiro (1998).
} 
sendo o mesmo incapaz de influenciar o nível de preço internacional e, desta forma, defrontando-se com uma função de demanda externa infinitamente preço-elástica. Neste caso, o modelo se resume à estimação de equações de oferta de exportação. A segunda opção reside na suposição de uma função de demanda por exportação com elasticidadepreço finita, associada à grande participação no mercado mundial ou à produção de bens diferenciados, e uma função de oferta perfeitamente elástica, alicerçada na existência de capacidade ociosa na indústria doméstica ou de uma tecnologia produtiva sujeita a retornos constantes ou crescentes de escala. A estimação resume-se, então, à equação de demanda. Finalizando, a terceira possibilidade parte de um modelo no qual preço e quantidade exportados são determinados simultaneamente pela interação das funções de oferta é demanda com elasticidades-preço finitas.

As possíveis variáveis condicionantes de demanda por exportação são, até certo ponto, restritas. Tratam-se, basicamente, de alguma variável que represente o nível de renda externa real passível de ser alocada no consumo de bens exportáveis e variáveis de preço relativo, relacionando o preço dos produtos exportados aos preços vigentes de bens substitutos no mercado internacional. Porém, alegam os autores, a efetiva definição das variáveis depende do produto, país e/ou período analisado e disponibilidade de dados.

Níveis de renda agregada ou de importações de um subgrupo relevante de países ou dos países na totalidade são exemplos de proxies da variável renda externa destinada à aquisição de tradeables. Os autores indicam que o procedimento mais adequado é a utilização de índices relativos aos principais parceiros comerciais do país de interesse, ponderados pela participação dos mesmos nas exportações desse país. Da mesma forma, a escolha dos preços dos bens substitutos no mercado internacional pode recair em índices de preços mundiais ou preços relevantes para os parceiros comerciais, em geral, preços de importação ou algum índice representativo dos tradeables.

As funções de oferta de exportações, ao contrário das funções de demanda, possuem uma grande quantidade de variáveis condicionantes (ou explicativas), dada a 
gama de fatores que pode afetar a capacidade e/ou disposição dos produtores de certo país em produzir e exportar seus produtos.

Da mesma forma que em outros trabalhos aqui abordados, uma variável que represente a capacidade produtiva, com caráter tendencial, também é citada como condicionante da oferta de exportação. Adicionalmente, os autores citam a possibilidade de serem inseridas no modelo determinantes da capacidade produtiva (como níveis de produtividade, taxas de investimento etc.). Variáveis associadas aos ciclos de atividade interna, captando a premissa de que as exportações são, em grande parte, uma alternativa para reduzir e/ou evitar o aumento da capacidade ociosa na produção interna. Ainda em relação a variáveis associadas aos ciclos de atividade interna, os autores argumentam que sua utilização é mais plausível para os produtos manufaturados, pois, para tais produtos, o conceito de utilização da capacidade instalada faz pleno sentido.

Segundo os autores, a rentabilidade real da atividade exportadora se configura como a principal classe de variáveis explicativas da oferta de exportação. Para eles, tal rentabilidade pode ser avaliada pela comparação entre as receitas e despesas associadas com a atividade exportadora ou à remuneração das exportações relativamente às vendas no mercado doméstico. Para o primeiro caso, deve-se incorporar à análise indicadores apropriados dos custos inerentes à atividade, tais como salários reais, preços dos principais insumos, custos de comercialização etc. Na segunda opção, deve-se comparar a receita obtida com as exportações com a receita obtida da venda do produto no mercado doméstico. Por fim, em ambas as opções, deve-se utilizar um índice de incentivos existentes (fiscais e/ou creditícios) às vendas externas.

A comparação de rentabilidades, externa e interna, na mesma unidade monetária incorpora a taxa de câmbio real como variável de suma importância para as exportações, tanto no curto quanto no longo prazo. $O$ valor esperado e a variância da remuneração relativa das exportações são determinados, respectivamente, pelo nível e volatilidade da taxa de câmbio real, influenciando as exportações no curto prazo e as decisões de investimento em atividades exportadoras no longo prazo. A formulação típica da taxa de 
rentabilidade das exportações é "dada pela multiplicação do índice de preços de exportação pela taxa de câmbio nominal e por algum índice de incentivos à atividade exportadora, divididos pelo índice de preço do mercado doméstico." (Cavalcanti \& Ribeiro, 1998, p.19) Adota-se, portanto, a hipótese de homogeneidade no preço, ou seja, variações em cada componente dessa taxa produzem efeitos de magnitude (absoluta) idêntica.

Finalizando, os autores concluem que as especificações representadas pelas equações (2.4.22) e (2.4.23) são as mais comuns para as funções de oferta e demanda de' exportação de certo país:

$$
\begin{gathered}
X^{D}=X^{D}\left(P_{X} / P_{W}, Y_{W}\right) \\
X^{S}=X^{S}\left(P_{X} S_{X} E / P_{d}, C_{d}, U, Y_{p}\right)
\end{gathered}
$$

onde:

$X^{S}$ quantidade ofertada de exportação;

$X^{D}$ quantidade demandada de exportação;

$Y_{W}$ proxy da renda mundial;

$P_{X}$ Preço das exportações;

$P_{W}$ Preço dos bens substitutos;

$S_{X}$ Índice de incentivos às exportações;

$E$ taxa de câmbio nominal;

$P_{d}$ Índice de preços doméstico dos produtos exportados;

$C_{d}$ Índice de custo de insumos e/ou fatores de produção;

$U$ taxa de utilização da capacidade produtiva;

$Y_{p}$ Índice de produto potencial. 
Citam os autores que no início dos anos 80, existiam duas abordagens predominantes, a especificação baseada na hipótese de país pequeno e a especificação de modelos nos quais preço e quantidade eram determinados simultaneamente, conforme descrito anteriormente. Tais formulações se baseavam na estimação de equações estruturais especificadas ad hoc, considerando as variáveis como estacionárias, sem a realização de qualquer teste que pudesse comprovar a validade da pressuposição. Corrigindo esse erro, os autores se propõem a estimar equações de exportação com especificações comprovadas a partir de testes apropriados.

Nesse sentido, foram realizados os testes ADF (Dickey-Fuller Aumentado) com o intuito de determinar a ordem de integração das variáveis. Em segundo lugar, realizouse a análise de co-integração, através do método de Máxima Verossimilhança de Johansen (1988). O terceiro teste diz respeito à consistência dos vetores de co-integração encontrados com os argumentos teóricos apresentados. Em geral, apenas um vetor de cointegração foi encontrado no trabalho, buscando-se, então, verificar se essa relação poderia ser interpretada como uma função de oferta, de demanda ou como uma forma reduzida. Caso existissem dois vetores, poderia, um deles, ser identificado como uma relação de oferta, e o outro, como uma relação de demanda. Testou-se, por fim, a existência de exogeneidade fraca das variáveis explicativas para os parâmetros de longo prazo, cuja aceitação implica na possibilidade de estimação das relações de longo prazo e realização de inferências estatísticas, sem perda de eficiência, com modelos uniequacionais. Aceita tal hipótese, os autores procederam a estimação de uma equação auto-regressiva com defasagens distribuídas (ADL), em sua forma original ou sob a forma de um Modelo de Correção de Erro (MCE), o qual possibilita uma análise da dinâmica de curto prazo das exportações.

Carvalho \& Negri (2000) estimaram equações trimestrais para o quantum de produtos agropecuários importados e exportados pelo Brasil, sendo para as exportações considerado o período entre 1977 e 1998. Os autores utilizaram o procedimento de 
Johansen (1988) para a análise de co-integração, para, em seguida, testar a presença de exogeneidade fraca das variáveis. Para as importações, admite-se a exogeneidade fraca das variáveis explicativas, baseando-se, em parte, na hipótese de que o Brasil é um pequeno país importador. As relações de curto e longo prazos foram estimadas por meio de um Modelo de Correção de Erro (MCE).

No modelo proposto para o estudo das exportações, foram consideradas:

a) leve diferenciação entre os produtos domésticos e estrangeiros, isto é, os produtos estrangeiros são substitutos imperfeitos dos domésticos;

b) preços diferenciados;

c) equações básicas:

$$
\begin{aligned}
& X^{d}=f\left(P_{x}, P_{d}^{*}, Y^{*}, T^{*}\right) \\
& X^{s}=f\left(E . P_{x}, P_{d}, S, Y\right) \\
& X^{s}=X^{d}
\end{aligned}
$$

onde $X^{s}$ e $X^{d}$ referem-se à oferta e demanda de exportação, respectivamente; $P_{x}$ é o preço das exportações; $Y$ o produto; $E$ a taxa de câmbio nominal; $P_{d}, 0$ preço doméstico; $T$, a tarifa de exportação; e $S$, os subsídios às exportações. Os asteriscos associados às variáveis significam que elas referem-se ao mercado externo.

Diante da impossibilidade de supor-se, a priori, a exogeneidade dos preços relativos em relação aos parâmetros das equações (2.4.25) e (2.4.26), iniciaram-se as estimações por meio de um modelo VAR (Vetor Auto-Regressivo) e, em seguida, realizou-se o teste de co-integração via procedimento de Johansen. Constatada a relação estável entre as variáveis, o teste de exogeneidade fraca das variáveis explicativas tornou-se passível de ser realizado (Banerjee et al, $1993^{35}$, citados pelos autores). A

\footnotetext{
${ }^{35}$ BANERJEE, A.; DOLADO, J.J.; GALBRAITH, J.W. et al. Co-integration, error-correction and the econometric analysis of non-stationary data. Oxford: Oxford University Press, 1993.
} 
aceitação da hipótese nula de exogeneidade fraca possibilitou a simplificação das estimações, especificando-se um modelo uniequacional representado por:

$$
X=f\left(\left(E . P_{x} .(1+S) / P_{d}\right), Y, Y^{*}\right)
$$

Considerando a existência de ilusão monetária e agrupamento de preços (os efeitos oriundos de alterações de preços, tarifas e subsídios são idênticos), especificamse as seguintes funções de oferta de exportação:

$$
\begin{gathered}
X=f\left(\left(E . P_{x} .(1+S) / P_{d}\right), Y / Y^{p}, Y, Y^{*}\right) \\
X=f\left(\left(E . P_{x} .(1+S) / P_{d}\right), Y^{p}, \dot{Y}, Y^{*}\right)
\end{gathered}
$$

$\mathrm{Na}$ equação (2.4.24) inclui-se uma variável representativa da capacidade instalada $(Y / Y p)$, gerando a equação (2.4.25) e uma variável representando o produto potencial $(Y p)$, gerando a equação (2.4.26).

Braga \& Markwald (1983) chamam a atenção para o fato de que os modelos uniequacionais, cuja especificação inclui variáveis relacionadas à oferta e à demanda por exportações, podendo-se citar neste último caso a variável representando a renda do resto do mundo, não são fundamentados na hipótese de país pequerio, pois os modelos estruturais que dão origem à forma reduzida consideram tanto funções de oferta como de demanda com elasticidades finitas.

Miranda (2001) estudou o comportamento das exportações brasileiras de carne bovina ajustando uma equação reduzida que denominou de equação de vendas. Para a especificação dessa equação, considerou que a quantidade do produto ofertada pelo 
Brasil no mercado externo é igual ao excedente do produto no mercado doméstico, podendo-se escrever:

$$
X^{s}=S-D
$$

na qual:

$X^{s}$ é o produto ofertado para o mercado externo;

$S$ a quantidade ofertada domesticamente; e

$D$ a demanda interna.

Tem-se que:

$$
\begin{gathered}
S=f\left(p_{d}, p_{b}, W\right) \\
D=g\left(P_{d}, V\right)
\end{gathered}
$$

com:

$P_{d} \quad$ sendo o preço doméstico em reais;

$P_{b} \quad$ o preço de exportação em reais;

$W$ representando deslocadores da oferta;

$V$ representando deslocadores da função de demanda.

Substituindo (2.4.28) e (2.4.29) em (2.4.27) tem-se a equação de oferta de exportação:

$$
X^{s}=h\left(P_{b}, W, V\right)
$$

A equação de demanda de exportação pode ser expressa por: 


$$
X^{D}=j\left(P_{x}, P w, Z\right)
$$

sendo:

$P w$ é o preço do produto concorrente no mercado internacional;

$Z$ representa deslocadores da demanda externa do produto;

$P_{x}$ é o preço das exportações em dólar, com $P_{x}=\frac{P_{b}}{T_{C}}$, onde $T_{C}$ é a taxa de câmbio real.

Em equilibrio, tem-se:

$$
X^{*}=X^{s}=X^{d}
$$

sendo $X^{*}$ a quantidade negociada no mercado externo, ou ainda,

$$
X^{*}=k\left(P_{b}, W_{i}, Y_{i}\right)=l\left(P_{x}, P_{w}, Z\right)
$$

e como $P_{x}=\frac{P_{b}}{T_{C}}$

a equação de vendas pode ser escrita da seguinte forma:

$$
X^{*}=m(P x, P w, T C, V, W, Z)
$$

Os deslocadores das funções de oferta e demanda de exportações considerados na análise foram a renda interna, proxy para a renda externa e variáveis representando a tendência e a sazonalidade das exportações. 
Barros et al. $(2001)^{36}$ elaboraram um modelo teórico para a análise das exportações brasileiras de produtos agropecuários, considerados individualmente. Os autores, na formulação desse modelo, definiram a oferta e a demanda domésticas como sendo, na forma logarítmica:

$$
\begin{array}{cc}
q^{s}=\Phi+\gamma p_{d}+\mu f & \gamma>0, \mu<0 \\
q^{d}=\varphi+\eta p_{d}+\theta y & \eta<0, \theta>0
\end{array}
$$

onde $q^{s}$ e $q^{d}$ são, respectivamente, as quantidades oferecida e demandada, $p_{d}$ é o preço, $f$ é um deslocador da oferta e $y$ é a renda per capita.

Em equilibrio, tem-se que:

$$
q^{s}=q^{d}
$$

Deste modo:

$$
\Phi+\gamma p_{d}+\mu f=\varphi+\eta p_{d}+\theta y
$$

A partir dessa igualdade, obtém-se:

$$
p_{d}^{*}=[(\varphi-\Phi)+\theta y-\mu f] /(\gamma-\eta)
$$

onde (2.4.37) representa o (logaritmo do) preço doméstico de equilibrio, que vigora na ausência de comércio com $o$ exterior.

${ }^{36}$ BARROS, G.S.C.; BACCHI, M.R.P.; BURNQUIST H.L. Estimação de Equações de Oferta de Exportação de Produtos Agropecuários para o Brasil (1992/2000). Piracicaba: CEPEA/ESALQ, 2001. 71p.(Estudo apresentado ao Instituto de Pesquisa Econômica Aplicada - IPEA) 
Considera-se que o produto doméstico seja passível de ser exportado ao preço $p_{x}$, expresso em moeda do país exportador. Considera-se, ainda, que o produto selecionado para exportação reduz a disponibilidade interna (elevando o preço doméstico), sem influenciar o nível de qualidade do produto comercializado internamente, assumindo-se que não há controle rigoroso de sua qualidade.

Relacionando o preço externo, $p_{x}$, e o interno, $p_{d}$, tem-se uma margem de exportação, $M=p_{x} / p_{d}$, que cobre o custo dessa operação. $\mathrm{O}$ preço externo é determinado no mercado internacional e seu valor não sofre influência do volume exportado pelo país em questão, isto é, considera-se que a demanda externa para o referido produto seja perfeitamente elástica.

Admite-se que a margem $m$ (representada na forma logarítmica) seja relacionada a $p_{d}$ :

$$
m=\alpha \cdot p_{d}
$$

onde $\alpha$ é a elasticidade que relaciona $m$ e $p_{d}$.

Sendo que $p_{x}=p_{d}+m$, tem-se que:

$$
p_{d}=p_{x}-m=p_{x}-\alpha \cdot p_{d}
$$

Assim, pode-se reescrever as equações (2.4.35) e (2.4.36) como:

$$
\begin{aligned}
& q^{s}=\Phi+\gamma p_{x}-\gamma \alpha p_{d}+\mu f \\
& q^{d}=\varphi+\eta p_{x}-\eta \alpha p_{d}+\theta y
\end{aligned}
$$


Pode-se, agora, proceder a especificação da oferta de exportação, que é definida como o excesso de oferta sobre a demanda doméstica. Assim sendo, ela envolve as mesmas variáveis que afetam essas duas funções. Dessa maneira, pode-se representá-la genericamente em logaritmo como:

$$
q^{x}=g\left(p_{x}, p_{d}, f, y\right)
$$

onde $q^{x}=\ln Q^{x}$, para $Q^{x}=Q^{s}-Q^{d}$, sendo que as variáveis descritas por letras maiúsculas representam as respectivas quantidades, e não seus logaritmos.

Sabendo-se que:

$$
\frac{d Q^{x}}{Q^{x}}=\left(\frac{Q^{s}}{Q^{x}}\right) \cdot \frac{d Q^{s}}{Q^{s}}-\left(\frac{Q^{d}}{Q^{x}}\right) \cdot \frac{d Q^{d}}{Q^{d}}
$$

conclui-se que a elasticidade de qualquer variável sobre a oferta de exportação será a diferença entre as elasticidades dessa variável sobre a oferta e demanda domésticas, cada uma ponderada pela relação entre quantidades totais e quantidades exportadas. Por exemplo, a elasticidade de $P_{x}$ sobre $Q_{x}$ é dada por:

$$
\frac{\left(\frac{d Q^{x}}{Q^{x}}\right)}{\left(\frac{d P^{x}}{P^{x}}\right)}=\frac{Q^{s}}{Q^{x}} \cdot\left[\frac{\left(\frac{d Q^{s}}{Q^{s}}\right)}{\left(\frac{d P^{x}}{P^{x}}\right)}\right]-\frac{Q^{d}}{Q^{x}} \cdot\left[\frac{\left(\frac{d Q^{d}}{Q^{d}}\right)}{\left(\frac{d P^{x}}{P^{x}}\right)}\right]
$$

na qual os termos entre colchetes do segundo membro da equação são as elasticidades de oferta e demanda domésticas em relação a $P_{x}$. Dessa forma, considerando $\left(2.4 .35^{\prime}\right) \mathrm{e}$ (2.4.36'), pode-se dizer que: 


$$
\lambda_{p x}=k_{x}(\gamma-\eta)
$$

sendo $\lambda_{p x}$ a elasticidade de $Q_{x}$ em relação a $P^{x}$ e $k_{x}=Q^{s} / Q^{x} \approx Q^{d} / Q^{x}$.

Da mesma forma:

$$
\lambda_{p d}=-k_{x} \alpha(\gamma-\eta)
$$

é a elasticidade da oferta de exportação em relação a $P_{d}$.

E ainda:

$$
\lambda_{y}=-k_{x} \theta
$$

onde $\lambda_{y}$ é a elasticidade da oferta de exportação em relação à renda doméstica.

Na Figura 3, representam-se as curvas de oferta e demanda domésticas, $q^{s}$ e $q^{d}$. Considera-se que $p_{d}{ }^{*}$ é o preço doméstico e $q^{*}$ a quantidade de equilíbrio na ausência de comércio com o exterior.

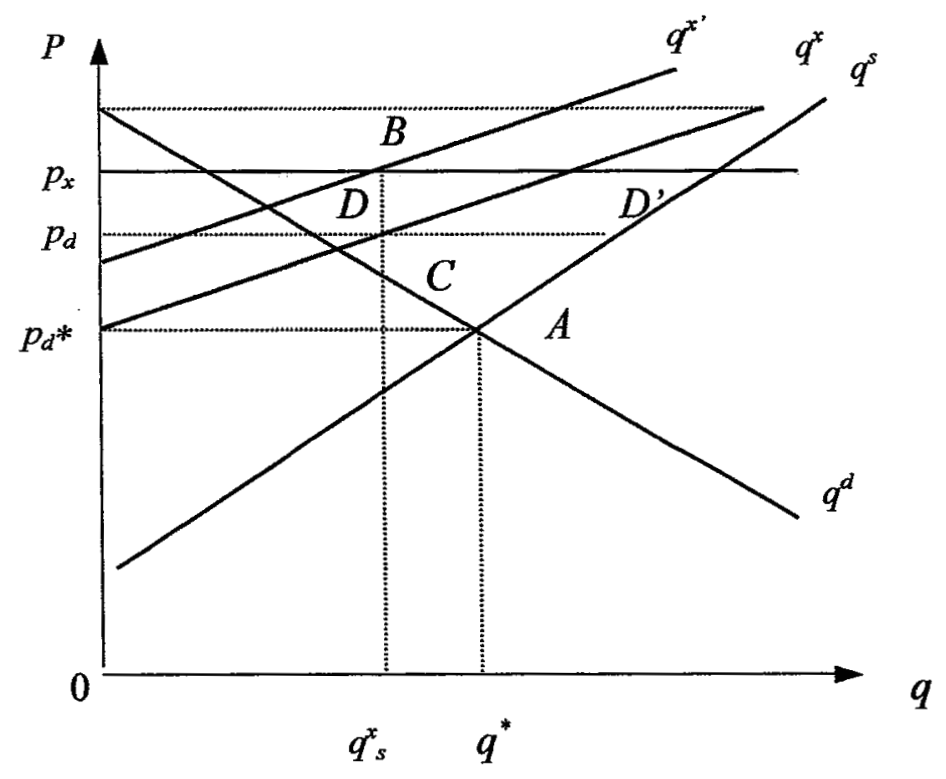

Figura 3 - Função de oferta de exportação. 
Existindo a possibilidade de comércio exterior, faz-se necessária a obtenção da curva de oferta de exportação, $q^{x^{\prime}}$. Para isso, primeiramente, obtém-se a linha correspondente ao excesso de oferta do mercado interno, $q^{x}=q^{s}-q^{d}$, para preços acima de $p_{d}{ }^{*}$. Obtida essa linha, adiciona-se à mesma a margem de exportação, originando, então, a curva de oferta de exportação, $q^{x^{\prime}}$. Considera-se, agora, uma demanda por exportação perfeitamente elástica, dada pela linha $p_{x}$. Assim, $p_{x}$ é o preço FOB de exportação, $p_{d}$ é o preço doméstico e a quantidade vendida no exterior é $q^{x}{ }_{s}=p_{x} B=p_{d} C=D D^{\prime}$.

Retornando à equação (2.4.40), tem-se que a oferta por exportação é dada por:

$$
q^{x}=g\left(p_{x}, p_{d}, f, y\right)
$$

Sabendo-se que:

$$
p_{x}=p_{e} T_{c}
$$

na qual $p_{e}$ é o preço das exportações em moeda estrangeira e $T_{c}$ a taxa de câmbio nominal, pode-se reescrever a equação (2.4.40) como:

$$
q^{x}=g\left(p_{e}, T_{c}, p_{d}, f, y\right)
$$

Os estudos apresentados, exceto o de Miranda (2001) e de Barros et al. (2001), tratam de equações de exportação de agregados. No presente estudo, foram estimadas equações de exportação para o mercado de frango, buscando a aplicação da metodologia clássica de comércio internacional para setores específicos da economia, o que pode contribuir para as decisões dos agentes do mercado e para a definição de políticas setoriais. 


\section{METODOLOGIA}

\subsection{Modelo teórico}

Conforme discutido, existem quatro abordagens básicas para a especificação de um modelo de exportação.

A primeira utiliza o pressuposto de país pequeno, quando as exportações do país considerado constituem uma fração pouco representativa do total comercializado mundialmente, sendo portanto incapazes de influenciar o nivel de preço internacional. Essa hipótese implica na existência de uma função de demanda infinitamente preçoelástica, restringindo o modelo à estimação de uma equação de oferta de exportação.

A segunda opção reside na suposição de uma função de demanda por exportação com elasticidade-preço finita e uma função de oferta perfeitamente elástica. Tais suposições estão associadas: a uma significativa participação no mercado mundial ou à produção de bens diferenciados (atributos relacionados à demanda), e à existência de capacidade ociosa na indústria doméstica ou de uma tecnologia produtiva sujeita a retornos constantes ou crescentes de escala (atributos relacionados à oferta). Nesse caso, a estimação resume-se à equação de demanda.

A terceira possibilidade parte de um modelo no qual preço e quantidade exportados são determinados simultaneamente pela interação das funções de oferta e demanda com elasticidades-preço finitas. 
A quarta e última abordagem trata da estimação de uma equação reduzida que tem como regressores as variáveis que explicam o comportamento da oferta e da demanda de exportação, que pode ser especificada ad hoc ou com base em um modelo estrutural. Utiliza-se, no presente estudo, a primeira abordagem, na qual a função de demanda é considerada infinitamente elástica e a estimação resume-se à equação de oferta de exportação. No entanto, essa função de oferta de exportação não é típica, sendo que a sua derivação resultou em uma função que incorpora o preço doméstico como variável explicativa.

Parte-se do pressuposto de que a oferta de exportação seja expressa como o excesso de oferta do mercado doméstico. Conforme apresentado no capítulo anterior, Zini Junior. (1988) argumenta que durante os períodos de expansão da economia doméstica, os produtores podem preferir suprir esse mercado, preservando, assim, seu market share. Tais suposições fundamentam a modelagem formulada por Barros et al. (2001), a qual será utilizada no presente estudo para a análise das exportações de frango.

Considerando o market share do frango brasileiro no mercado internacional, a hipótese de uma demanda por exportação infinitamente elástica mostra-se plausível. Embora restrições de comércio e a existência de certa dependência em relação a fornecedores habituais possam abrir espaço para críticas sobre tal hipótese, acredita-se que essa abordagem seja consistente para os objetivos propostos (Zini Junior, 1988).

Braga \& Markwald (1983) consideram, como discutido, que a utilização da forma log-linear é indicada para o ajustamento das equações pelo fato de que as elasticidades são obtidas diretamente dos resultados da regressão e, ao contrário das formas lineares, são constantes e independem dos valores assumidos pelas variáveis. Miranda (2001) salienta, ainda, que o uso de logaritmos pode auxiliar na solução do problema de heterocedasticia (variância do erro não-constante). $O$ modelo proposto por Barros et al. (2001), conforme exposto anteriormente, é formulado em logaritmos. 


\subsection{Modelo empírico}

Embora seja inegável a importância das exportações brasileiras de cortes especiais de frango, 48,11\% do total exportado em 2000 contra $51,89 \%$ de frango inteiro (carcaça), optou-se por trabalhar com o total exportado de frango, ou seja, considerou-se a existência de um mercado único.

O modelo expresso por $\left(2.4 .35^{\prime}\right)$ e $\left(2.4 .36^{\prime}\right)$ pode ser representado pelas seguintes funções matemática:

$$
\begin{aligned}
& q_{t}^{s}=a_{0}+a_{1} p_{d, t}+a_{2} f_{t} \\
& q^{d}{ }_{t}=b_{0}+b_{1} p_{d, t}+b_{2} r_{r_{, t}}
\end{aligned}
$$

onde $f$ representa um deslocador da função de oferta, podendo se usado para captar efeitos tecnológicos ou comportamento estacional. Por sua vez, o deslocador da demanda, $r_{r}$, representa a renda real da população.

Considera-se a margem $m$ (na forma logarítmica), relacionada a $p_{d}$ :

$$
m_{t}=\alpha \cdot p_{d, t}
$$

onde $\alpha$ é a elasticidade.

Sendo que $p_{x, t}=p_{d, t}+m_{t}$, tem-se:

$$
p_{d, t}=p_{x, t}-m_{t}=p_{x, t}-\alpha \cdot p_{d, t}
$$

Assim, com base na equação (3.2.4), podem-se reescrever (3.2.1) e (3.2.2) como: 


$$
\begin{gathered}
q^{s}{ }_{t}=a_{0}+a_{1} p_{x_{,} t}-a_{1} \alpha p_{d, t}+a_{2} f_{t} \\
q^{d}{ }_{t}=b_{0}+b_{1} p_{x, t}-b_{1} \alpha p_{d, t}+b_{2} r_{r, t}
\end{gathered}
$$

Considerando-se que:

$$
p_{x, t}=p_{e, t} c_{r, t}
$$

na qual $p_{e}$ é o preço das exportações em moeda estrangeira e $c_{r}$ a taxa de câmbio nominal, pode-se reapresentar as equações (3.2.1') e (3.2.2') da seguinte forma:

$$
\begin{aligned}
& q^{d}{ }_{t}=b_{0}+b_{1} p_{e, t}+b_{1} c_{r, t}-b_{1} \alpha p_{d, t}+b_{2} r_{r, t} \\
& q^{s}=a_{0}+a_{1} p_{e, t}+a_{1} c_{r, t}-a_{1} \alpha p_{d t}+a_{2} f_{t}
\end{aligned}
$$

Dessa maneira, em equilíbrio, tem-se:

$x_{t}^{s}=a_{0}+a_{1} p_{e, t}+a_{1} c_{r, t}-a_{1} \alpha p_{d, t}+a_{2} f_{t}-b_{0}-b_{1} p_{e, t}-b_{1} r_{r, t}+b_{1} \alpha p_{d, t}-b_{2} r_{r, t}$

rearranjando os termos:

$x_{t}^{s}=\left(a_{0}-b_{0}\right)+\left(a_{1}-b_{1}\right) p_{e, t}+\left(a_{1}-b_{1}\right) c_{r, t}-\left(a_{1}-b_{1}\right) \alpha p_{d, t}+a_{2} f_{t}-b_{2} r_{r, t}$

Renomeando os coeficientes e expressando a equação (3.2.5') como um modelo estatístico que envolve um termo representando o erro estocástico $\left(\varepsilon_{t}\right)$ tem-se:

$$
x_{t}^{s}=c_{0}+c_{1} p_{e, t}+c_{2} c_{r, t}-c_{3} p_{d, t}+c_{4} f_{t}-c_{5} r_{r, t}+\varepsilon_{t}
$$

sendo: 
$c_{0}=\left(a_{0}-b_{0}\right)$

$c_{1}=\left(a_{1}-b_{1}\right)$

$c_{2}=\left(a_{1}-b_{1}\right)$

$c_{3}=\alpha \cdot\left(a_{1}-b_{1}\right)$

$c_{4}=a_{2} ;$

$c_{5}=b_{2}$

Espera-se coeficiente positivo para as variáveis preço externo e câmbio e negativos para preço interno e renda. Para fins de simplificação, excluiu-se do modelo o termo representativo de deslocadores de oferta.

\subsection{Procedimentos econométricos}

No modelo de análise de regressão clássico, pressupõe-se que o termo errático possua média zero e variância finita e invariante no tempo. Pressupõe-se, ainda, que as séries sejam estacionárias ou tornem-se estacionárias após serem diferenciadas. Segundo Kassouf (1988), estacionariedade existe se a série desenvolve-se no tempo aleatoriamente em torno de uma média constante, refletindo alguma forma de equilibrio estável.

A utilização de séries não-estacionárias, ou seja, de séries que apresentem tendência estocástica, pode levar à obtenção de regressão espúria. $\mathrm{O}$ termo "regressão 
espúria", segundo Griffiths et al. (1993) ${ }^{37}$, citados por Anéfalos \& Margarido (1999), surgiu a partir do trabalho desenvolvido por Granger \& Newbold $(1974)^{38}$, que descobriram que os resultados de um processo estocástico independente não possuíam significado econômico, apesar das estimativas dos parâmetros obtidos serem significativas e do alto valor apresentado pelo coeficiente da determinação $\left(R^{2}\right)$. Se uma série apresenta tendência estocástica, um choque existente no período $t$ não diminuirá com o passar do tempo, o que é uma situação que dificilmente se observa no mundo real. Gujarati (1995) afirma que, ao ajustar uma regressão entre duas séries de tempo, o problema de regressão espúria ocorre porque as séries envolvidas apresentam tendência estocástica comum, o que explica o alto valor do $R^{2}$, mesmo não existindo relação entre as variáveis. Por essa razão, enfatiza o autor, torna-se muito importante descobrir se o relacionamento entre variáveis econômicas é verdadeiro ou não.

A aplicação dos testes de raiz unitária tem por objetivo identificar se uma série é ou não-estacionária. Existem diversos testes para verificar a existência de raiz unitária em séries temporais, destacando-se os desenvolvidos por Fuller (1976) e Dickey \& Fuller $(1979,1981)$ e por Phillips \& Perron (1988), baseado em Phillips (1987). Na maior parte das análises que envolvem procedimentos econométricos utilizou-se o teste de Dickey-Fuller Aumentado (ADF) para verificar a existência de raiz unitária nas séries utilizadas, o que será feito também neste estudo.

O teste de Dickey-Fuller considera um processo auto-regressivo de ordem um [AR(1)]:

$$
y_{t}=\rho y_{t-1}+u_{t}
$$

sendo $u_{t}$ erros aleatórios identicamente e independentemente distribuídos.

\footnotetext{
${ }^{37}$ GRIFFITHS, W.E.; HILL, R.C.; JUDGE, G. Learning and practicing econometrics. New York: John Wiley \& Sons, 1993. 866p.

${ }^{38}$ Estudo também utilizado por Enders (1995) para explicar o referido termo.
} 
Através da estimação da equação (3.3.1) pelo método de Mínimos Quadrados Ordinários (MQO), testa-se a hipótese de que $y_{t}$ é não-estacionária (hipótese nula). Tem-se portanto:

$$
\begin{aligned}
& H_{0}: \rho=1 \\
& H_{a}:|\rho|<1
\end{aligned}
$$

Compara-se o valor do teste $t$ do modelo ajustado com o valor crítico da distribuição denominada estatística $\tau$, obtida por Fuller (1976), considerando um dado nível de significância. A não-rejeição da hipótese nula indica a existência de raiz unitária e, conseqüentemente, que a série é não-estacionária.

Outra maneira de se realizar o teste de Dickey-Fuller (DF) é através da reparametrização de (3.3.1), subtraindo-se $y_{t-1}$ de ambos os lados da equação. Estimase, então, por Mínimos Quadrados Ordinários (MQO), a equação resultante:

$$
\Delta y_{t}=(\rho-1) y_{t-1}+u_{t}
$$

na qual:

$\Delta y_{t}-$ série $y_{t}$ em primeira diferença;

$y_{t-1}$ - série $y_{t}$ defasada em um período;

$u_{t} \quad$ - ruído branco.

testando-se, neste caso, a hipótese:

$$
\begin{gathered}
H_{0}: \rho-1=0 \\
H_{a}: \rho-1<0 \\
\operatorname{com} \rho-1 \in(-2,0)
\end{gathered}
$$


Nesse modelo, pressupõe-se que não há intercepto (drift) nem tendência determinística. Se isso não ocorrer, os valores críticos das estatísticas $\tau$ não se aplicam (Holden \& Perman, 1994 ${ }^{39}$, citado por Anéfalos \& Margarido, 1999). Para a realização do teste de raiz unitária, é preciso conhecer, a priori, o processo gerador dos dados, para então escolher o modelo a ser usado para o teste - incluindo ou não componentes deterministicos (tendência e constante). Incluindo constante $\left(\mu_{b}\right)$ e constante e tendência (T) na equação (3.3.3), obtêm-se respectivamente:

$$
\begin{gathered}
\Delta y_{t}=\mu_{b}+\lambda y_{t-1}+u_{t} \\
\Delta y_{t}=\mu_{b}+\lambda y_{t-1}+\gamma_{c} T+u_{t}
\end{gathered}
$$

$\operatorname{com}: \lambda=(\rho-1)$.

Existe, para cada modelo considerado, uma estatística pertinente para testar a presença de raiz unitária na série, conforme será apresentado adiante.

Dickey \& Fuller (1981) forneceram também estatísticas que possibilitam testar conjuntamente a presença de um termo de intercepto ou intersepto/tendência e de raiz unitária. Essas estatísticas, denominadas $\phi_{1}, \phi_{2}$ e $\phi_{3}$, correspondem a estatísticas $F$. A Tabela 10 apresenta um sumário dos testes propostos pelos autores e as respectivas hipóteses.

39 HOLDEN, D.; PERMAN, R. Unit roots and cointegration for the economist. In: RAO, B.B. Cointegration for the applied economist, New York: ST. Martin Press, p.47-94, 1994. 
Tabela 10. Sumário dos testes de Dickey-Fuller.

\begin{tabular}{ccc}
\hline Modelo & Hipóteses & Estatística \\
\hline$\Delta y_{t}=\mu_{b}+\lambda y_{t-1}+\gamma_{c} T+u_{t}$ & $\lambda=0$ & $\tau_{\tau}$ \\
$\mu_{b}=0$ dado $\lambda=0$ & $\tau_{\alpha \tau}$ \\
$\gamma_{c}=0$ dado $\lambda=0$ & $\tau_{\beta \tau}$ \\
$\lambda=\gamma_{c}=0$ & $\phi_{3}$ \\
$\mu_{b}=\lambda=\gamma_{c}$ & $\phi_{2}$ \\
$\Delta y_{t}=\mu_{b}+\lambda y_{t-1}+u_{t}$ & $\lambda=0$ & \\
$\Delta y_{t}=\mu_{b}+\lambda y_{t-1}+u_{t}$ & $\mu_{b}=0$ dado $\lambda=0$ & $\tau_{\alpha \tau}$ \\
& & $\mu_{b}=\lambda=0$
\end{tabular}

Fonte: Enders (1995)

A seleção do modelo que melhor se ajusta ao processo gerador dos dados e os testes para analisar a presença de raiz unitária devem seguir procedimentos seqüenciais. Do mesmo modo que Rochelle (2000), neste estudo, utilizar-se-á aquele sugerido por Doldado, Jenkinson \& Sosvilla-Rivero (1990), modificado por Enders (1995), representado na Figura 4. 
Estimar: $\Delta y_{t}=\mu_{b}+\lambda y_{t-1}+\sum_{i=1}^{p-1} \omega_{i} \Delta y_{t-i}+\gamma_{c} T+u_{t}$
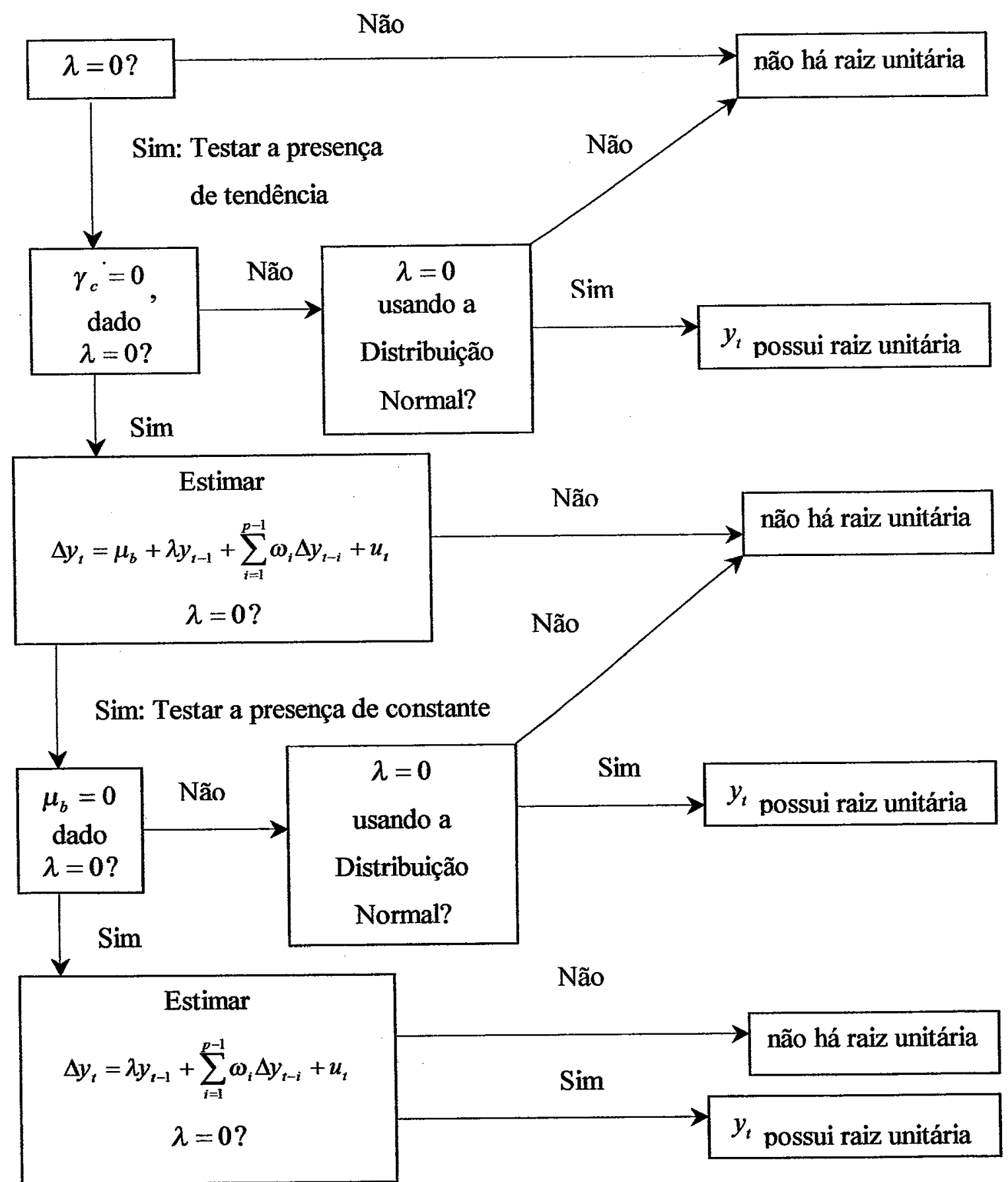

Figura 4 - Procedimento seqüencial para testar a presença de raiz unitária.

Fonte: Enders (1995). 
Como mencionado, o teste de Dickey-Fuller (DF) pressupõe que o processo gerador dos dados é um processo auto-regressivo de ordem um [AR(1)]. Se um modelo [AR(1)] for usado quando, de fato, a variável $y_{t}$ é representada por um processo autoregressivo de ordem $p[\operatorname{AR}(p)]$, com $p>1$, os erros apresentarão autocorrelação para compensar a falha na estrutura dinâmica de $y_{t}$. A citada autocorrelação dos resíduos invalida a utilização do teste Dickey-Fuller (DF).

Assim sendo, considerando-se que a série seja descrita por um processo autoregressivo de ordem $p[\operatorname{AR}(p)]$, a seguinte equação deve ser ajustada:

$$
y_{t}=\rho_{1} y_{t-1}+\ldots+\rho_{p} y_{t-p}+u_{t}
$$

Esse teste corresponde ao de Dickey-Fuller Aumentado (ADF). Reparametrizando a equação (3.3.6), obtém-se:

$$
\Delta y_{t}=\mu_{b}+\lambda y_{t-1}+\sum_{i=1}^{p-1} \omega_{i} \Delta y_{t-i}+\gamma_{c} T+u_{t}
$$

na qual:

$$
\begin{aligned}
\lambda & =\sum_{i=1}^{p} \rho_{i}-1 \\
\omega_{i} & =-\sum_{j=i+1}^{p} \rho_{j}
\end{aligned}
$$

Testa-se:

$$
\begin{aligned}
& H_{0}: \lambda=0 \\
& H_{a}: \lambda<0
\end{aligned}
$$


Do mesmo modo que no teste de Dickey-Fuller (DF), o valor calculado da estatistica $t$ deve ser comparado com o valor crítico da correspondente estatística $\tau$, (considerando a inclusão ou não de componentes determinísticos, drift e tendência). Se a hipótese nula não for rejeitada, o processo é não-estacionário, devendo-se repetir o teste descrito em (3.3.7) com uma diferença a mais, verificando, assim, se a série $y_{t}$ é estacionária na primeira diferença. Se a hipótese nula não for rejeitada novamente, devese aumentar o número de diferenças até que o teste se apresente significativo (Rochelle, 2000).

Para a realização dos testes de Dickey-Fuller (DF) e de Dickey-Fuller Aumentado (ADF), pressupõe-se que os erros são independentes e têm variância constante. $\mathrm{O}$ valor de $(p)$ deve ser tal que torne $u_{t}$ uma série ruído branco.

A correta determinação do número de defasagens a ser incluído no modelo é muito importante, visto que a inclusão de poucas defasagens pode conduzir à rejeição da hipótese nula sendo esta verdadeira, enquanto que a inclusão de muitas defasagens reduz o poder do teste, uma vez que parâmetros adicionais são estimados (Enders, 1995).

A ordem do processo auto-regressivo [AR $(p)]$, para fins dos testes de DickeyFuller, pode ser determinada através de diversos critérios de informação. Neste estudo, serão utilizados o Akaike Information Criterion (AIC) e o Schwarz Criterion (SC), que estão entre os critérios de informação mais utilizados ${ }^{40}$. Estes são representados, respectivamente, pelas equações:

$$
\begin{gathered}
A I C=\ln s^{2}+(2 / T)\left(n^{o} \text { de parâmetros }\right) \\
S C=\ln s^{2}+(\ln T / T)\left(n^{o} \text { de parâmetros }\right)
\end{gathered}
$$

nas quais:

\footnotetext{
${ }^{40}$ Cavalcanti \& Ribeiro (1998) e Carvalho \& Negri (2000) utilizam ambos os testes.
} 
$s^{2}$ - a soma de quadrados dos resíduos;

$T$ - número de observações.

A ordem do processo auto-regressivo é determinada pelo menor valor obtido nesses critérios, considerando-se uma seqüência de ajustamentos, sendo que o número de defasagens do modelo aumenta sucessivamente.

Embora muito utilizados, os testes para verificar a existência de raiz unitária apresentam certa limitação, inerente a qualquer método de análise econométrica. Desse modo, é importante discutir as limitações verificadas na aplicação desses testes, as quais devem ser consideradas na análise dos resultados.

Enders (1995) argumenta que, formalmente, o poder de um teste é igual à probabilidade de rejeição da hipótese nula, sendo ela falsa, isto é, um menos a probabilidade de se cometer erro do tipo II (probabilidade de não rejeitar a hipótese nula, dado que ela é falsa). Simulações de Monte Carlo mostram que o poder dos testes de raiz unitária $^{41}$ é muito pequeno, o que impossibilita distinguir processos com raiz unitária daqueles que possuem raízes próximas da unidade. Logo, esses testes podem indicar erroneamente a presença de raiz unitária..

Adicionalmente, Enders (1995) discute que embora o processo de diferenciação seja muito útil para transformar séries não-estacionárias em estacionárias, nem sempre é possivel utilizar a diferenciação como meio para se obter a estacionariedade de uma série integrada de ordem $d$.

Existem dois tipos de séries não-estacionárias: aquelas com tendência estocástica (difference stationary - DS), cuja tendência é removida por diferenciação, tornando a série estacionária; e aquelas com tendência determinística (trend stationary - TS), a qual é retirada através de uma regressão que inclua uma variável tendência. Para se

${ }^{41}$ Tais como os testes de Dickey-Fuller (1979 e 1981) e Phillips-Perron (1987). 
determinar se uma série possui tendência deterministica ou estocástica, deve-se seguir os passos de 1 a 4 do procedimento proposto por Holden \& Perman (1994).

Outro problema reside na escolha do número de defasagens a ser incluído no modelo para testar a presença de raiz unitária. A utilização de diversos critérios pode resultar em indicações distintas quanto a esse número, produzindo, em geral, diferentes resultados em relação à rejeição da hipótese nula de não-estacionariedade. Assim sendo, é fundamental determinar corretamente o número de defasagens a ser incluído no modelo, interligando, se necessário, mais de um método.

Se as séries usadas em um modelo econômico forem integradas, é necessário que o modelo econométrico utilizado para obter as relações entre as variáveis seja especificado com as séries nas diferenças. No entanto, se existir co-integração entre as variáveis, um termo de correção de erro deve ser incluído no modelo para representar o comportamento de longo prazo.

Segundo Harris (1995) ${ }^{42}$, citado por Rochelle (2000), a interpretação econômica de co-integração é de que, se duas (ou mais) séries integradas de ordem $d$ estão unidas para formar uma relação de equilibrio de longo prazo, então, elas se moverão juntas ao longo do tempo de tal forma que a diferença entre as mesmas seja estável (estacionária). Assim, o conceito de co-integração está relacionado à existência de um equilíbrio de longo prazo, para o qual um sistema econômico converge ao longo do tempo.

Uma vez que o conceito de co-integração está associado a uma relação de equilibrio, é possível obter importantes informações acerca das relações de longo prazo das variáveis consideradas no modelo, pois, nesse caso, as inferências estatísticas a partir dos resultados dos testes $t \mathrm{e} F$ são aplicáveis mesmo que as variáveis individualmente não sejam estacionárias.

\footnotetext{
${ }^{42}$ HARRIS, R.I.D. Using cointegration analysis in econometric modeling. London: Prentice Hall, 1995. 176p.
} 
Se duas séries, $x_{t}$ e $y_{t}$, são ambas integradas de ordem $d[I(d)]$, qualquer combinação linear dessas séries será também $\mathrm{I}(d)$ e, por conseguinte, a série de resíduos de uma regressão envolvendo essas variáveis, também será $\mathrm{I}(d)$. Contudo, pode haver uma combinação linear das séries $\mathrm{I}(d)$ onde o termo errático da regressão $\left(z_{t}=y_{t}-a x_{t}\right)$ seja de uma ordem de integração menor, $\mathrm{I}(d-b)$, para $b>0$. Neste caso, diz-se que as séries são co-integradas. Supondo que $d=b=1$, têm-se:

$$
\begin{aligned}
x_{t} & \sim I(1) \\
y_{t} & \sim I(1)
\end{aligned}
$$

mas,

$$
z_{t}=\left(y_{t}-\alpha x_{t}\right) \sim I(0)
$$

onde $a$ é denominado vetor de co-integração (Portugal, 1992).

Assim, as séries $x_{t}$ e $y_{t}$ são definidas como sendo séries co-integradas de ordem um $[\mathrm{CI}(1,1)]$.

Dentre os métodos mais utilizados para testar co-integração, tem-se o proposto por Engle \& Granger (1987) como um dos principais. Esses autores sugerem um procedimento em duas etapas para testar a existência de co-integração entre variáveis. A primeira envolve a estimação da relação de longo prazo pelo método de Mínimos Quadrados Ordinários (MQO) e a realização de testes para identificar a existência de raiz unitária nos resíduos dessa regressão. $\mathrm{Na}$ segunda etapa, estima-se o Modelo de Correção de Erro (MCE), que representa a dinâmica de curto prazo das variáveis cointegradas.

A primeira etapa do processo definida pelos autores, divide-se em dois passos. $\mathrm{O}$ primeiro, que possibilita a execução dos testes de co-integração sob o enfoque apresentado, é verificar a ordem de integração $\mathrm{I}(d)$ das variáveis. Por definição, para que 
duas (ou mais) séries sejam co-integradas, é preciso que elas apresentem a mesma ordem de integração $\mathrm{I}(d) .^{43}$

O passo seguinte consiste em estimar a relação de longo prazo entre as variáveis $x_{t}$ e $y_{t}$, através da estimação da equação (3.3.14) pelo método de Mínimos Quadrados Ordinários (MQO):

$$
y_{t}=a_{0}+a_{1} x_{t}+z_{t}
$$

Sendo as variáveis co-integradas, obtêm-se estimadores "superconsistentes" dos parâmetros de co-integração $a_{0} \mathrm{e} a_{1}$. Conforme essa propriedade dos estimadores, se $y_{t}$ e $\quad x_{t}$ são variáveis não-estacionárias, integradas de ordem um, $I(1)$ e $z_{t} \sim I(0)$, ao aumentar o tamanho da amostra, os estimadores de mínimos quadrados convergem mais rapidamente para seu valor verdadeiro do que no caso de variáveis estacionárias, $I(0)$ (Stock, $1987^{44}$, citado por Portugal, 1992 e Harris, 1995).

Para testar a hipótese de que $x_{t}$ e $y_{t}$ são não co-integradas, segundo o enfoque de Engle \& Granger (1987), testa-se a hipótese nula, $z_{t} \sim I(1)$, contra a hipótese alternativa, $z_{t} \sim I(0)$. A rejeição da hipótese nula implica que os residuos são estacionários e, como as variáveis $x_{t}$ e $y_{t}$ são $I(1)$, pode-se concluir que as séries são co-integradas de ordem um [CI(1,1)]. Tal qual no primeiro passo, deve-se utilizar testes de raiz unitária para testar a estacionariedade dos resíduos. ${ }^{45}$

\footnotetext{
${ }^{43}$ Note que, se ambas forem estacionárias, interrompe-se o teste, pois os métodos de estimação tradicionais se aplicam às variáveis estacionárias. Da mesma forma, se as variáveis forem integradas de ordens diferentes, conclui-se que elas são não co-integradas.

${ }^{44}$ STOCK, J. Asymptotic properties of least squares estimators of cointegrating vector. Econometrica, v.55, p.381-386, 1987.

${ }^{45}$ Para testar a presença de raiz unitária nos resíduos da relação de longo prazo entre as variáveis, devem ser usados os valores fornecidos por Engle \& Granger (1987) e Engle \& Yoo (1992).
} 
A principal característica de variáveis co-integradas é que seu comportamento no tempo é caracterizado por desvios em relação ao equilíbrio de longo prazo. Tais desvios influenciam a dinâmica de curto prazo dessas variáveis, implicando na necessidade de se considerar um mecanismo de correção de erros (Engle \& Granger, 1987). Os autores provaram a existência de isomorfismo entre o mecanismo de correção de erros e um processo co-integrado. O Teorema de Representação de Granger mostra que, se duas séries são co-integradas, então, existe um mecanismo de correção de erros e vice-versa.

Identificada co-integração entre as variáveis, deve-se estimar um Modelo de Correção de Erro que representa a citada dinâmica de curto prazo. Os resíduos da equação de longo prazo, defasados de um período, captam os desvios em relação ao equilibrio de longo prazo e são usados para estimar o MCE. Portanto, se $x_{t}$ e $y_{t}$ são cointegradas de ordem um, $[\mathrm{CI}(1,1)]$, o Modelo de Correção de Erro pode ser representado pela seguinte equação (3.3.15):

$$
\Delta y_{t}=b_{0} \widehat{z}_{t-1}+\sum_{i=1} c_{i} \Delta x_{t-i}+\sum_{i=1} d_{i} \Delta y_{t-i}+e_{t}
$$

sendo $\widehat{z}_{t-1}=y_{t-1}-a_{0}-a_{1} x_{t-1}$ a estimativa do desvio da relação de equilíbrio de longo prazo no período (t-1), isto é, é o termo ou mecanismo de correção de erro.

A equação (3.3.15) deve ser estimada por MQO e, posteriormente, deve-se verificar a adequação do modelo. Os resíduos não devem apresentar autocorrelação serial e o coeficiente estimado do termo de correção de erro (também chamado de coeficiente de velocidade de ajustamento) deve ser estatisticamente diferente de zero, se as variáveis são co-integradas.

A análise das relações de co-integração através do método proposto por Engle \& Granger (1987) apresenta certas limitações. Embora não tenha problema para grandes amostras, Stock, op. cit., encontrou evidência de um viés relativamente grande para 
pequenas amostras. Este viés é especialmente relevante em regressões co-integradas com $\mathrm{R}^{2}$ baixo. Adicionalmente, o mesmo não é indicado para os casos em que se considera a possibilidade de existir mais de um vetor de co-integração ${ }^{46}$, ou quando exista endogeneidade do regressor [relação causal no sentido da variável dependente para a(s) explicativa(s)].

Para sanar tais deficiências, pode-se utilizar o método de Johansen (1988), com o objetivo de definir o número de vetores de co-integração.

A descrição do referido método inicia-se pela representação de um VAR (Vetor Auto-Regressivo) de dimensão $p$ :

$$
\mathbf{x}_{t}=A_{1} \mathbf{x}_{t-1}+A_{2} \mathbf{x}_{t-2}+\ldots+A_{p} \mathbf{x}_{t-p}+\varepsilon_{t}
$$

onde $\mathbf{x}_{\mathbf{t}}$ é um vetor com $k$ variáveis e $\varepsilon_{t} \sim N I I D(0, \Omega)$.

Pode-se reescrever o modelo VAR da seguinte forma:

$$
\Delta \mathbf{x}_{t}=\Gamma_{1} \Delta \mathbf{x}_{t-1}+\Gamma_{2} \Delta \mathbf{x}_{t-2}+\ldots+\Gamma_{k-1} \Delta \mathbf{x}_{t-p+1}+\Gamma_{k} \Delta \mathbf{x}_{t-p}+\varepsilon_{t}
$$

nas quais:

$\Gamma_{i}=-I+A_{1}+\ldots+A_{i}$ para $i=1,2, \ldots, p$

de modo que $\Gamma_{k}=A(1)=-I+A_{1}+A_{2}+\ldots+A_{k}$

\footnotetext{
${ }^{46}$ Isso ocorre quando se tem mais de uma variável explicativa, o que é comum. Nesses casos, a utilização do método Engle-Granger resultará na estimação de uma combinação linear de diferentes vetores cointegrados, onde, somente nos casos em que os vetores co-integrados são iguais, o método de dois estágios levará a um resultado sensato (Portugal, 1992).
} 
O procedimento de Johansen baseia-se na seguinte versão reparametrizada do $\operatorname{VAR}(p)$.

$$
\Delta \mathbf{x}_{\mathrm{t}}=\Gamma_{1} \Delta \mathbf{x}_{\mathbf{t}-1}+\ldots+\Gamma_{p-1} \Delta \mathbf{x}_{\mathbf{t}-\mathbf{p}+1}+\Pi \mathbf{x}_{\mathbf{t}-1}+\mu+\varphi \mathbf{d}_{\mathrm{t}}+\varepsilon_{t}
$$

na qual $d_{t}$ é um vetor de variáveis binárias para captar a variação estacional.

Considerando que $r$ seja o posto da matriz П. Então $\Pi$ tem $r$ autovalores diferentes de zero. Três situações podem ocorrer: $\operatorname{se} r=k$ então $\mathbf{x}_{\mathbf{t}}$ é estacionário; se $r=$ 0 então $\Delta x_{\mathfrak{t}}$ é estacionário; finalmente, se $0<r<k$ existem matrizes $\alpha$ e $\beta$ de dimensão $k \times r$ tais que $\Pi=\alpha \beta^{\prime}$ e o vetor $\beta^{\prime} \mathbf{x}_{\mathbf{t}}$ é estacionário, havendo, portanto, $r$ vetores de co-integração (as $r$ colunas de $\beta$ ). Johansen \& Juselius (1990) mostraram como se pode tomar decisão sobre o valor de $r$ com base nas séries temporais observadas. Esses autores apresentaram dois testes, bem como seus valores críticos, para identificar o número de vetores de co-integração: teste do traço e do $\lambda_{\max }$. $\mathrm{O}$ teste do traço é dado por:

$$
-2 \ln (Q)=-T \sum_{i=r+1}^{\mathrm{n}} \ln \left(1-\lambda_{\mathrm{i}}\right)
$$

e o teste $\lambda_{\max }$ é simplesmente a diferença entre estatísticas-traço consecutivas.

Os critérios AIC (Akaike Information Criterion) e SC (Schwarz Criterion), num contexto multiequacional, são utilizados para a determinação do valor de $p$.

A metodologia de Johansen (1988) é utilizada no presente estudo para analisar co-integração entre as variáveis do modelo proposto. 


\subsection{Dados utilizados}

O estudo das exportações brasileiras de frango foi feita com dados mensais do período de janeiro de 1991 a dezembro de 2000. A escolha desse período foi determinada pelo início da abertura da economia brasileira e o crescimento contínuo ${ }^{47}$ das exportações nesses anos.

Todos os procedimentos econométricos foram realizadas utilizando-se o software RATS (Regression Analysis Time Series) for Windows, versão 4.30.

As variáveis utilizadas e suas respectivas fontes são descritas a seguir.

O montante de carne de frango exportado mensalmente foi obtido junto à Associação Paulista de Avicultura (APA), através da revista Aves \& Ovos. Os dados apresentados nessa publicação têm como referência a Secretaria de Comércio Exterior (SECEX).

A indisponibilidade dos dados de preço efetivo de exportação conduziu à utilização do valor médio como proxy, obtido pela divisão do valor total exportado mensalmente, em dólares, pela quantidade total exportada correspondente. Os dados referentes ao valor total exportado, tal qual o do montante exportado, foram obtidos na revista Aves \& Ovos, que tem como referência a SECEX. Aguiar $(1995)^{48}$, citado por Miranda (2001), comenta que tal procedimento tem sido muito utilizado e destaca que, embora muitos resultados mostrem-se coerentes, é de se esperar que exista uma defasagem entre o preço de fechamento do negócio e o registro da exportação.

A série de preços internos de carne de frango foi obtida junto ao Instituto de Economia Agrícola - IEA, sendo deflacionada pelo Índice Geral de Preços - IGP.

\footnotetext{
${ }^{47}$ Ocorre certa ređução em 1995, primeiro ano após o Plano Real, período de intensa apreciação cambial.

${ }^{48}$ AGUIAR, D.R.D. (Ed.) Comércio internacional e comercialização agrícola. Viçosa: Universidade Federal de Viçosa, 1995. 328p.
} 
Os dados usados para taxa de câmbio real foram os obtidos por Miranda (2001). A autora calculou a taxa de câmbio real considerando a taxa de câmbio nominal (valor de compra - em reais por dólar), o Índice de Preço ao Produtor - IPP (todas as commodities), para os Estados Unidos da América (obtido na página do Bureau of Labor Statistics - http://stats.bls.gov/datahome.htm) e o Índice Geral de Preços Disponibilidade Interna (IGP-DI) do Brasil.

Em relação à renda doméstica, utilizou-se o PIB a custo de fatores índice real como proxy. Essa série foi obtida na página do IPEA - http://www.ipeadata.gov.br.

Utilizaram-se na análise nove variáveis dummies para captar os efeitos de possíveis deslocamentos do quantum exportado em diferentes anos de abrangência do estudo. Isso permite melhorar o ajustamento do modelo em caso de existir um padrão diferenciado das exportações nos diversos anos considerados na análise.

No próximo capítulo, serão apresentados e discutidos os resultados obtidos a partir da estimação do modelo proposto para a análise da oferta brasileira de exportação de frango. 


\section{RESULTADOS E DISCUSSÃO}

Os resultados apresentados são os obtidos através do ajustamento da equação (3.2.5"), definida no capítulo anterior, acrescida do termo de correção de erro. Tal especificação deve-se à existência de uma relação de longo prazo entre as variáveis, ou seja, à existência de co-integração.

Para estimação do modelo, realizaram-se, primeiramente; os testes para a identificação do processo auto-regressivo das séries consideradas na análise. Os testes utilizados, conforme já mencionado, foram os de Akaike Information Criterion (AIC) e o Schwarz Criterion (SC). Em seguida, realizaram-se os testes de raiz unitária, segundo os procedimentos apresentados por Enders (1995). Fizeram-se, então, os testes de cointegração desenvolvidos por Johansen (1988) para determinar a existência e o número de vetores de co-integração. O presente capítulo estará estruturado de acordo com a ordenação descrita acima, sendo apresentados os resultados e comentários acerca dos testes.

\subsection{Resultados dos testes de raiz unitária}

Os resultados dos critérios de Akaike (AIC) e Schwarz (SC), apresentados na Tabela 11, indicam que a série de quantidade exportada de frango $\left(q_{e}\right)$ é descrita por um processo auto-regressivo de ordem sete, $\operatorname{AR}(7)$, enquanto que a série de renda real 
$\left(r_{r}\right)$ é descrita por um processo auto-regressivo de ordem doze, AR(12). A Tabela 11 mostra também os resultados para as séries de preço interno real $\left(p_{d}\right)$, preço de exportação em dólares $\left(p_{e}\right)$ e câmbio real $\left(c_{r}\right)$. Ocorre, no entanto, que, para essas séries, os valores encontrados com o AIC e o SC diferem. Nesse caso, a determinação do número de defasagens da variável dependente utilizado nos testes de raiz unitária foi feita obedecendo ao princípio de parcimônia (manter o menor número de defasagens possível), conciliado à necessidade de não-existência de autocorrelação de resíduos. ${ }^{49}$

Considerando a sistemática proposta, foi determinado que a série de preço interno deveria ser expressa por um processo auto-regressivo de ordem sete, $\operatorname{AR}(7)$, e que as séries de preço de exportação de frango e de câmbio real deveriam ser expressas por um processo AR(4).

Finalizada a identificação dos processos auto-regressivos das séries, realizam-se os dos testes de raiz unitária e Dickey-Fuller Aumentado (ADF), cujos valores críticos são apresentados por Fuller (1976) e Dickey \& Fuller (1981). O procedimento utilizado para a realização dos testes é o descrito por Enders (1995), apresentado no capítulo anterior.

\footnotetext{
${ }^{49}$ Essa verificação deu-se através da estatística $Q$ de Ljung-Box.
} 
Tabela 11. Resultados de AIC e SC das séries consideradas na função de oferta de exportação de frango.

\begin{tabular}{cccccccccccc}
\hline \multirow{2}{*}{$\begin{array}{c}\text { Número } \\
\text { Defasagens }\end{array}$} & \multicolumn{2}{c}{$q_{e}$} & \multicolumn{2}{c}{$p_{d}$} & \multicolumn{2}{c}{$p_{e}$} & & $c_{r}$ & & $r_{r}$ \\
& \cline { 2 - 13 } & AIC & SC & AIC & SC & AIC & SC & AIC & SC & AIC & SC \\
\hline 1 & 222,761 & 228,126 & 67,048 & $72,412^{*}$ & $-176,217$ & $-170,852$ & $-107,798$ & $-102,434^{*}$ & $-201,833$ & $-196,469$ \\
2 & 205,002 & 213,049 & 68,945 & 76,991 & $-188,006$ & $-179,959^{*}$ & $-108,587$ & $-100,540$ & $-201,903$ & $-193,856$ \\
3 & 198,528 & 209,257 & 66,262 & 76,990 & $-186,006$ & $-175,277$ & $-106,754$ & $-96,025$ & $-200,373$ & $-189,644$ \\
4 & 191,715 & 205,126 & 64,716 & 78,126 & $-192,204^{*}$ & $-178,793$ & $-109,135^{*}$ & $-95,725$ & $-198,390$ & $-184,979$ \\
5 & 188,058 & 204,151 & 66,681 & 82,773 & $-192,001$ & $-175,908$ & $-107,141$ & $-91,048$ & $-196,992$ & $-180,899$ \\
6 & 188,473 & 207,248 & 65,446 & 84,221 & $-190,028$ & $-171,253$ & $-105,280$ & $-86,505$ & $-196,234$ & $-177,459$ \\
7 & $180,216^{*}$ & $201,673 *$ & $63,084 *$ & 84,541 & $-188,034$ & $-166,577$ & $-106,328$ & $-84,871$ & $-201,821$ & $-180,364$ \\
8 & 181,651 & 205,790 & 63,929 & 88,069 & $-186,106$ & $-161,967$ & $-104,524$ & $-80,385$ & $-208,209$ & $-184,070$ \\
9 & 183,649 & 210,470 & 64,472 & 91,293 & $-184,201$ & $-157,379$ & $-104,092$ & $-77,270$ & $-211,352$ & $-184,530$ \\
10 & 185,399 & 214,902 & 65,372 & 94,875 & $-183,147$ & $-153,644$ & $-102,112$ & $-72,608$ & $-216,850$ & $-187,346$ \\
11 & 187,390 & 219,575 & 65,885 & 98,071 & $-182,090$ & $-149,904$ & $-100,124$ & $-67,939$ & $-217,279$ & $-185,094$ \\
12 & 185,352 & 220,220 & 65,976 & 100,843 & $-180,343$ & $-145,476$ & $-98,379$ & $-63,512$ & $-235,006^{*}$ & $-200,138^{*}$ \\
\hline
\end{tabular}

Fonte: Dados da pesquisa.

* Valores críticos 
Os resultados desses testes para as séries utilizadas no modelo, em nível, são apresentados na Tabela 12. A obtenção de valores não-significativos das estatísticas $\tau_{\tau}$, $\tau_{\beta \tau}, \phi_{3}, \tau_{\mu}, \tau_{\alpha \mu}$ e $\phi_{1}^{50}$, apresentados na referida tabela, indicam que o modelo que melhor se ajusta ao processo gerador das séries não inclui os elementos determinísticos tendência e constante. Logo, a estatística $\tau$ deve ser utilizada para a análise de raiz unitária nas séries.

Tabela 12. Resultados dos testes de identificação de raiz unitária e de elementos determinísticos das séries, em nível, utilizados na estimação da função de oferta de exportação de frango.

\begin{tabular}{cccccccc}
\hline Séries & \multicolumn{7}{c}{ Estatísticas } \\
\cline { 2 - 7 } (em nível) & $\tau_{\tau}$ & $\tau_{\beta \tau}$ & $\phi_{3}$ & $\tau_{\mu}$ & $\tau_{\alpha \mu}$ & $\phi_{1}$ & $\tau$ \\
\hline$q_{e}$ & $-2,26$ & 2,37 & 2,83 & $-0,06$ & 0,10 & 0,01 & 2,00 \\
$p_{d}$ & $-2,64$ & $-2,08$ & 3,99 & $-1,87$ & $-2,18$ & $4,78^{*}$ & 0,24 \\
$p_{e}$ & $-0,58$ & $-1,70$ & 2,40 & $-1,36$ & 1,13 & 1,29 & $-0,78$ \\
$c_{r}$ & $-1,93$ & 1,29 & 2,84 & $-1,99$ & 1,88 & 3,55 & $-0,64$ \\
$r_{r}$ & $-0,79$ & 0,67 & 0,42 & $-0,63$ & 0,71 & 0,50 & 3,97 \\
\hline
\end{tabular}

Fonte: Dados da pesquisa.

* significativo a $5 \%$

A não-significância dos testes de Dickey-Fuller Aumentado (DFA) para as estatísticas $\tau$ indica a presença de raiz unitária em todas as séries em nível. Por essa razão, com as séries nas primeiras diferenças e uma defasagem a menos, repetiram-se os testes.

Os resultados dos testes DF, obtidos com as séries nas primeiras diferenças, são apresentados na Tabela 13 e mostram que, nesse caso, todas as séries utilizadas no

\footnotetext{
${ }^{50}$ Embora a estatística $\phi_{1}$ apresente um valor significativo para a variável preço doméstico, a realização do teste individual para a constante indicou que ela é não-significativa, o que motivou a realização do teste de raiz unitária com o modelo sem constante.
} 
modelo são estacionárias, pois, ao nível de significância de $1 \%$, rejeitou-se a hipótese de raiz unitária. Pode-se afirmar, então, que as séries são integradas de ordem um, I(1).

Tabela 13. Resultados dos testes de identificação de raiz unitária e de elementos determinísticos das séries, nas primeiras diferenças, utilizadas na estimação da função de oferta de frango.

Séries na primeira diferença

Estatística

\begin{tabular}{lllll}
\multicolumn{6}{c}{ Séries na primeira diferença } \\
\hline$q_{e}$ & $p_{d}$ & $p_{e}$ & $c_{r}$ & $r_{r}$
\end{tabular}

\begin{tabular}{llllll}
$\tau$ & $-8,32 * *$ & $-7,46 * *$ & $-5,28 * *$ & $-8,27^{* *}$ & $-7,39^{* *}$ \\
\hline
\end{tabular}

Fonte: Dados da pesquisa.

$* *$ significativo a $1 \%$

\subsection{Resultados dos testes de co-integração}

Uma vez determinada a ordem de integração das séries, utilizou-se o procedimento desenvolvido por Johansen (1988) para analisar a existência de co-integração, sendo os resultados apresentados na Tabela 14.

Os resultados obtidos em ambos os testes, Traço e $\lambda_{\text {max }}$, indicam a existência de dois vetores de co-integração. Dessa forma, incluem-se dois termos de correção de erro no modelo utilizado para analisar a oferta de exportação de frango, sendo mantido somente aquele que se apresentou significativo estatisticamente. 
Tabela 14. Resultados dos testes de co-integração obtidos através do procedimento de máxima verossimilhança de Johansen.

\begin{tabular}{ccc}
\hline Hipótese & $\lambda$ máximo & Traço \\
\hline$r \leq 4$ & 1,243 & 1,243 \\
$r \leq 3$ & 4,685 & 5,929 \\
$r \leq 2$ & 18,651 & 24,580 \\
$r \leq 1$ & $33,381^{*}$ & $57,961^{*}$ \\
$r=0$ & $64,651^{*}$ & $122,612^{*}$ \\
\hline
\end{tabular}

Fonte: Dados da pesquisa.

** significativo a $5 \%$

Obs: Modelo foi formulado com constante não-restrita e considerando uma defasagem, conforme indicavam os testes de AIC e SC para o contexto multivariado.

Valores críticos em Johansen \& Juselius (1990).

\subsection{Resultados da estimativa do Modelo de Correção de Erro (MCE)}

A seguinte função de oferta de exportação foi estimada:

$$
\begin{aligned}
& \Delta q_{e, t}=\alpha_{0}+\alpha_{1} \Delta p_{e, t}+\alpha_{2} \Delta c_{r, t}+\alpha_{3} \Delta p_{d, t}+\alpha_{4} \Delta r_{r, t}+\alpha_{5} D_{1, t}+\alpha_{6} D_{2, t}+\alpha_{7} D_{3, t}+ \\
& +\alpha_{8} D_{4, t}+\alpha_{9} D_{5, t}+\alpha_{10} D_{7, t}+\alpha_{11} D_{8, t}+\alpha_{12} D_{9, t}+\alpha_{13} z_{t-1}+\varepsilon_{t}
\end{aligned}
$$

na qual:

$\Delta$ é o operador de diferença;

$q_{e}$ é a quantidade exportada;

$p_{e}$ é o preço recebido pelas exportações em dólares;

$p_{d}$ é o preço real no mercado doméstico;

$c_{r}$ é a taxa de câmbio real; 
$r_{r}$ é a renda real (PIB);

$z$ é o termo de correção de erro;

$D_{i}(\operatorname{com} \mathrm{i}=1,2, \ldots, 8)$ são dummies anuais; $\mathrm{e}$

$\varepsilon$ é o termo de erro.

Tabela 15. Resultados da estimativa do Modelo de Correção de Erro utilizado para explicar a oferta de exportação brasileira de frango.

\begin{tabular}{|c|c|c|c|c|}
\hline \multirow{2}{*}{\multicolumn{2}{|c|}{$\begin{array}{ll}\text { Modelo: } & F(14,101)=8,4258 \\
\text { Variável }\end{array}$}} & $\overline{R^{2}}=0,538730$ & \multicolumn{2}{|c|}{ Variável dependente $=\Delta q$} \\
\hline & & Coeficiente & & Estatística $t$ \\
\hline & Constante & $-0,017871821$ & & $-0,30178$ \\
\hline & $\Delta p_{d}$ & $-0,338215378$ & $* *$ & $-2,42870$ \\
\hline & $\Delta p_{e}(3)$ & 0,445195376 & & 0,88667 \\
\hline & $\Delta c_{r}(2)$ & 0,467720931 & $* *$ & 2,04827 \\
\hline & $\Delta r_{r}(1)$ & $-1,358022547$ & $* *$ & $-2,52329$ \\
\hline & $\mathrm{z}$ & $-0,953386486$ & $*$ & $-9,80464$ \\
\hline & $D_{1}$ & $-0,161643369$ & $* * *$ & $-1,69312$ \\
\hline & $D_{2}$ & $-0,041778718$ & & $-0,50462$ \\
\hline & $D_{3}$ & 0,126748013 & & 1,52526 \\
\hline & $D_{4}$ & 0,044160364 & & 0,52093 \\
\hline & $D_{5}$ & $-0,104082330$ & & $-1,23866$ \\
\hline & $D_{6}$ & 0,146984028 & $* * *$ & 1,74659 \\
\hline & $D_{7}$ & 0,134988571 & & 1,61914 \\
\hline & $D_{8}$ & $-0,015955088$ & & $-0,19338$ \\
\hline & $D_{9}$ & 0,113054117 & & 1,35918 \\
\hline
\end{tabular}

Notas: * significativo a $1 \%$

** significativo a $5 \%$

*** significativo a $10 \%$

Obs: O número entre parênteses, apresentado em seqüência ao nome da variável, indica a ordem de defasagem considerada. 
Os resultados obtidos na estimação deste modelo são apresentados na Tabela 15 , acima, verificando-se, primeiramente, que o valor do coeficiente relacionado ao termo de correção de erro é estatisticamente diferente de zero, confirmando a existência de cointegração entre as variáveis do modelo proposto.

Quanto às demais variáveis explicativas que não as dummies, observou-se que os coeficientes apresentaram os sinais esperados, condizentes com a teoria econômica e com os conhecimentos empíricos. $\mathrm{O}$ coeficiente representativo da variável preço das exportações foi o único que não se mostrou estatisticamente significativo até $5 \%$ de probabilidade.

As dummies, como já discutido, foram introduzidas no modelo com o intuito de representar deslocamentos da oferta de exportação em diferentes anos de abrangência do estudo. Os resultados indicaram que em dois dos anos considerados na análise, os deslocamentos foram estatisticamente significativos considerando um nível de significância de até $10 \%$.

Os resultados obtidos apontam que o relacionamento entre algumas das variáveis explicativas e o quantum exportado se dá com defasagem de até três meses. Isso pode ocorrer, em alguma medida, pelo fato do fechamento do negócio ser feito, muitas vezes, antes do embarque do produto, quando a transação é então contabilizada. A situação conjuntural interna, no período estabelecido para o embarque, pode propiciar uma reversão da operação e, dessa forma, as variáveis de mercado interno teriam efeito mais imediato.

$O$ preço interno afeta negativamente o quantum exportado de frango. A elasticidade obtida indica que uma variação de $1 \%$ no preço interno causa uma variação de $0,33 \%$ na quantidade exportada. Variações de mesma magnitude nas demais variáveis explicativas incluídas no modelo têm impacto mais expressivo sobre as exportações do que o preço interno, sendo o maior efeito o de variação na renda interna . Uma variação de $1 \%$ na renda interna causa uma variação em sentido contrário de aproximadamente $1,35 \%$ na quantidade exportada. 
Os efeitos oriundos de choques nos preços das exportações e no câmbio real sobre o quantum exportado apresentam-se positivos. Uma variação de $1 \%$ no câmbio real causa variação de aproximadamente $0,46 \%$ no quantum exportado. Para o preço das exportações, o efeito é muito próximo, de $0,44 \%$. No entanto, a não-significância estatística do coeficiente representativo do preço das exportações sinaliza que se deve analisar a elasticidade associada à essa variável com cautela.

Um modelo alternativo no qual foi excluída a variável representativa do preço externo, cujo coeficiente apresentou-se não-significativo, foi ajustado e as elasticidades obtidas para a renda interna, preço interno e taxa de câmbio foram praticamente as mesmas obtidas anteriormente. 


\section{CONCLUSÕES}

O presente estudo teve por objetivo analisar a oferta de exportação brasileira de frango através da estimação de um modelo econométrico, fundamentado em um modelo teórico, proporcionando, assim, uma base plausível para a avaliação de fatores relevantes à interpretação do desempenho exportador desse segmento da economia, ao longo do período de abrangência da análise. As inferências feitas podem servir de base para a realização de análises prospectivas. No modelo teórico utilizado para atender a tais objetivos especifica-se a oferta de exportação como sendo determinada pela diferença entre a oferta e demanda interna.

O trabalho possibilitou a obtenção das estimativas das elasticidades de oferta de exportação com respeito às variáveis: preço doméstico, preço externo, renda interna $\mathrm{e}$ taxa de câmbio real. As estimativas apresentaram sinais coerentes com a teoria econômica e com o modelo teórico proposto. Os coeficientes das variáveis renda interna e preço interno apresentaram sinal negativo, indicando que o crescimento da absorção do produto no mercado doméstico, associado a um aquecimento da demanda agregada da economia e/ou a uma queda dos preços, reduzem as exportações de frango. Da mesma forma, uma redução do consumo doméstico contribui para a geração de maiores volumes de excedentes exportáveis de frango. Tais resultados sinalizam que o modelo teórico utilizado, que considera as exportações como sendo em grande parte determinadas pelos excedentes do mercado doméstico, mostrou-se apropriado para a análise proposta.A resposta das exportações de frango a uma variação na renda interna mostrou-se bastante expressiva - variação de $1 \%$ na renda interna causa uma variação de aproximadamente 
1,35\%, em sentido contrário, nas exportações do produto. Considera-se razoável relacionar o aumento do consumo interno de carne de frango, resultante de incrementos na renda, à importância desse produto protéico na dieta do consumidor brasileiro. Fica claro, então, que o crescimento da economia doméstica contribui para a diminuição das exportações, ocorrendo o contrário em caso de queda no PIB. Esse resultado leva à conclusão de que não é necessário adotar medidas intervencionistas para garantir o abastecimento doméstico, uma vez que o próprio mercado se encarrega de promover os ajustes necessários para que não ocorra falta ou sobra do produto.

Os preços internos tendem a espelhar o desempenho da produção doméstica relativamente à demanda interna, sendo esta já refletida no PIB. Nesse sentido, tem-se, por exemplo, que uma queda da produção devido a problemas sanitários poderia comprometer as exportações de frango através do aumento do preço interno desse produto. Sabe-se, no entanto, que o preço do frango, pelo fato do produto possuir grande flexibilidade no ajustamento da produção, seria pouco influenciado por alterações de oferta.

A elasticidade encontrada para o preço doméstico de frango indica que mudanças nessa variável teriam um impacto relativamente pequeno sobre as exportações - uma variação de $1 \%$ no preço doméstico provocaria uma variação de apenas $0,33 \%$ sobre as exportações. Isso sinaliza que variações da oferta (transmitidas através de variações do preço) sobre as exportações, caso ocorram, tenderiam a ter um efeito menos expressivo do que variações de mesma magnitude nas demais variáveis do modelo. Essa baixa elasticidade preço leva a concluir que a queda no preço doméstico decorrente de ganhos em produtividade, em virtude de uso de inovações tecnológicas, deveria ser expressiva para que as exportações pudessem aumentar de forma significativa.

A taxa de câmbio real apresentou-se como variável relativamente importante para estimular as exportações de carne de frango. $O$ efeito de mudanças na taxa de câmbio real sobre as exportações desse produto apresentou sinal positivo, indicando que quando a moeda doméstica sofre uma desvalorização real com relação às moedas dos 
principais parceiros comerciais brasileiros, as exportações são estimuladas. A elasticidade obtida para essa variável indica que um incremento de $1 \%$ no câmbio provoca um aumento da ordem de $0,46 \%$ nas exportações desse produto, após o período de dois meses.

O efeito do preço recebido pelo produto destinado ao mercado externo sobre o quantum exportado, embora seja positivo como esperado, apresentou-se nãosignificativo estatisticamente, sinalizando que foi estimado com baixa precisão. A magnitude do coeficiente relacionado a essa variável indica que uma alteração de $1 \%$ no preço externo ocasionaria um crescimento de aproximadamente $0,44 \%$ na quantidade exportada, após três meses.

Em termos gerais, pode-se considerar que o objetivo do presente estudo foi alcançado de forma bastante satisfatória. Dentre as variáveis relacionadas no modelo, a renda interna e a taxa de câmbio real foram as que apresentam as maiores elasticidades. $O$ preço externo e o interno, embora afetem as exportações brasileiras de frangos, fazerlo-iam de forma menos expressiva que a renda interna e o câmbio, para uma mesma variação percentual. No entanto, as políticas setoriais que propiciam um maior aumento da produtividade e queda no preço, por terem caráter mais independente do que as políticas macroeconômicas que afetam muitos segmentos da economia, parecem ser o melhor instrumento para se obter excedentes exportáveis.

As exportações brasileiras de frango vêm aumentando sua importância relativa na pauta das exportações de produtos agropecuários, que têm garantido a solvência do país, a despeito das turbulências financeiras trazidas pela globalização e um câmbio extremamente valorizado na maior parte do período pós-Real. Isso tem sido atribuído, principalmente, às condições altamente competitivas resultantes de um intenso desenvolvimento de produtos que atendam às preferências dos consumidores, além de inovações tecnológicas implementadas pelo setor. $\mathrm{O}$ frango brasileiro tornou-se um produto de alta aceitabilidade no mercado internacional, com condições concretas de expansão de seu market share. 
Fica claro, pelos resultados obtidos, que as exportações de frango dependem em grande parte de um ambiente macroeconômico adequado, uma vez que as duas variáveis mais relevantes na explicação das exportações são a renda interna e o câmbio. De outro lado, pode-se concluir que os investimentos em tecnologia, capazes de gerar excedentes exportáveis em condições competitivas são de suma importância para o desempenho das exportações. A avicultura brasileira vem experimentando, nas últimas décadas, grande desenvolvimento tecnológico, desenvolvimento este que se espera continue ocorrendo em alguma medida. 


\section{REFERÊNCIAS BIBLIOGRÁFICAS}

\section{ASSOCIAÇÃO BRASILEIRA DE PRODUTORES E EXPORTADORES DE}

FRANGO. Brazilian Chicken for people with sophisticated taste (compact disc). Rio de Janeiro: ABEF, 2000.

ANEFALOS, L.C.; MARGARIDO, M.A. Testes de raiz unitária e o software SAS. Agricultura em São Paulo, v.46, n.2, p.19-45, 1999.

* BARROS, G.S.C.; BITTENCOURT, M.V.L. Formação de preços sob oligopsônio: o mercado de frango em São Paulo. Revista Brasileira de Economia, v.51, n.2, p.181-199, abr./jun. 1997.

BONELLI, R.; HAHN, L. Resenha dos estudos recentes sobre relações comerciais brasileiras. Rio de Janeiro: IPEA, fev. 2000. 88p. (Texto para Discussão, 708)

BRAGA, H.C.; MARKWALD, R.A. Funções de oferta e de demanda das exportações de manufaturados no Brasil: estimação de um modelo simultâneo. Pesquisa e Planejamento Econômico, v.13, n.3, p.707-744, dez. 1983.

BRAGA, H.C.; ROSSI, J.W. A dinâmica da balança comercial no Brasil, 1970/1984. In: ENCONTRO BRASILEIRO DE ECONOMETRIA, 8., Brasília, 1986. Anais. Rio de Janeiro: SBE, 1986. v. 2, p.145-160. 
CARVALHO, A.; NEGRI, J.A. Estimação de equações de importação e exportação de produtos agropecuários para o Brasil (1977/1998). Rio de Janeiro: IPEA, jan. 2000. 30p. (Texto para Discussão, 698)

CARVALHO, A.; PARENTE, M.A. Estimação de equações de demanda de importações por categorias de uso para o Brasil (1978/1996). Rio de Janeiro: IPEA, abr. 1999. 31p. (Texto para Discussão, 636)

CASTRO, A.S.; CAVALCANTI, M.A.F.H. Estimação de equações de exportação e importação para o Brasil - 1955/95. Rio de Janeiro: IPEA, mar. 1997. 61p. (Texto para Discussão, 469)

CASTRO, A.S.; ROSSI JÚNIOR, J.L. Modelos de previsão para a exportação das principais commodities brasileiras. Rio de Janeiro: IPEA, abr. 2000. 34p. (Texto para Discussão, 716)

CAVALCANTI, M.A.F.H.; RIBEIRO, F.J. As exportações brasileiras no período 1977/96: desempenho e determinantes. Rio de Janeiro: IPEA, fev. 1998. 46p. (Texto para Discussão, 545)

DICKEY, D.A.; FULLER, W.A. Distribution of the estimator for auto-regressive time series with a unit root. Journal of the American Statistical Association, v.74, p.427-431, 1979.

DICKEY, D.A.; FULLER, W.A. Likelihood ratio statistics for auto-regressive time series with a unit root. Econometrica, v.49, p.1057-1072, 1981.

DOLDADO, J.; JENKINSON, T.; SOSVILLA-RIVERO, S. Cointegration and unit roots. Journal of Economic Surveys, v.4, p.249-273, 1990.

ENDERS, W. Applied econometric time series. New York: John Wiley \& Sons, 1995. $433 p$. 
ENGLE, R.F.;GRANGER, C.W.J. Cointegration and error correction: representation, estimation and testing. Econometrica, v.55, n.2, p.251-276, 1987.

ENGLE, R.F.; YOO, B.S. Forecasting and testing in co-integrated systems. Journal of Econometrics, v.35, p.143-159, 1987.

FULLER, W.A. Introduction to statistical time series. New York: John Wiley, 1976. $352 \mathrm{p}$.

裆 GONÇALVES, J.A. Exportações de aves começam a perder fôlego. Gazeta Mercantil. Finanças \& Mercados, São Paulo, 31 ago. 2001. p.B-16.

GOLDSTEIN, M.; KHAN, M.S. The supply and demand for exports: a simultaneous approach. The Review of Economics and Statistics, v.60, n.2, p.275-286, 1978.

GIULIETTI, N.; CRISCUOLO, P.D.; LINS, E.R. et al. Diagnóstico da avicultura no Brasil, 1970-78: contribuição para um programa de desenvolvimento. São Paulo: Instituto de Economia Agrícola, 1980. 278 p.

GUJARATI, D.N. Basic econometrics. 3.ed. New York: McGraw-Hill, 1995, 838p.

HOLDEN, D.; PERMAN, R. Unit roots and cointegration for the economist. In: RAO, B.B. Cointegration for the applied economist. New York: ST. Martin Press, p.4794, 1994.

JOHANSEN, S. Statistical analysis of cointegration vectors. Journal of Economic Dynamics and Control, v.12, p.231-54. 1988.

JOHANSEN, S.; JUSELIUS, K. Maximum likelihood estimation and inference on cointegration: with aplications to the demand for money. Oxford Bulletin of Economics and Statistics, v.52, p.169-219, 1990. 
KASSOUF, A.L. Previsão de preços na pecuária de corte no estado de São Paulo. Piracicaba, 1988. 102p. Dissertação (Mestrado) - Escola Superior de Agricultura "Luiz de Queiroz", Universidade de São Paulo.

LEAMER, E.; STERN, R. Quantitative international economics. Boston: Allyn and Bacon, 1970. 209p.

7 MARQUES, P.V. Economia da integração vertical na avicultura de corte do estado de São Paulo. Piracicaba, 1991. 131p. Tese (Livre-Docência) - Escola Superior de Agricultura “Luiz de Queiroz”, Universidade de São Paulo.

MIRANDA, S.H.G. de. Quantificação dos efeitos das barreiras não-tarifárias sobre as exportações brasileiras de carne bovina. Piracicaba, 2001. 233p. Tese (Doutorado) Escola Superior de Agricultura “Luiz de Queiroz", Universidade de São Paulo.

PHILLIPS, P.C.B. Time series with a unit root. Econometrica, v.55, n.2, p.277-301, 1987.

PHILLIPS, P.C.B; PERRON, P. Testing for a unit root in time series regression. Biometrika, v.75, n.2, p.335-346, 1988.

PINTO, M.B.P. O crescimento das exportações brasileiras de manufaturados, 19541974. Estudos Econômicos, v.10, n.3, p.101-143, 1980.

PINTO, M.B.P. Política cambial, política salarial e o potencial das exportações de manufaturados do Brasil no período 1954-1974. Revista Brasileira de Econometria, v.3, n.2, p.87-104, nov. 1983.

PORTUGAL, M.S. Um modelo de correção de erros para a demanda por importações brasileiras. Pesquisa e Planejamento Econômico, v.22, n.3, p.501-540, dez. 1992.

RIOS, S.M.C.P. Exportações brasileiras de produtos manufaturados: uma avaliação econométrica para o período 1964/84. Pesquisa e Planejamento Econômico, v.17, n.2, p.299-332, ago. 1987. 
特 RIZZI, A.T. Mudanças tecnológicas e reestruturação da indústria agroalimentar: o caso da indústria de frangos no Brasil. Campinas, 1993. 194p. Tese (Doutorado) Instituto de Economia, Universidade Estadual de Campinas.

ROCHELLE, T.C.P. Desenvolvimento do mercado futuro de algodão no Brasil e relações de preço no mercado de algodão em pluma. Piracicaba, 2000. 170p. Tese (Doutorado) - Escola Superior de Agricultura "Luiz de Queiroz", Universidade de São Paulo.

\$ SANTANA, A.C. Mudanças recentes nas relações de demanda de carne no Brasil. Revista de Economia e Sociologia Rural, v.37, n.2, p.51-76, 1999.

SORJ, B.; POMPERMAYER, M.J.; CORADINI, O.L. Camponeses e agroindústria: transformação social e representação política na avicultura brasileira. Rio de Janeiro: Zahar Editores, 1982. 119p.

ZINI JÚNIOR., A.A. Funções de exportação e de importação para o Brasil. Pesquisa e Planejamento Econômico, v.18, n.3, p.615-662, dez. 1988.

ZIRLIS, A.E.F.; LINS, E.R.; GIULIETTI, N. et al. Integração vertical, custos e receitas na avicultura de corte, no estado de São Paulo. Agricultura em São Paulo, v.37, n.3, p.147-173, 1990. 